\title{
Association between temperature and back pain among lumbar disc
}

\section{herniation patients}

Cai Chen ${ }^{1}$, Dandan Wang ${ }^{2}$, Fanjie $\mathrm{Liu}^{2}$, Hao $\mathrm{Qin}^{2}$, Xiyuan $\mathrm{Li}^{1}$, Fan $\mathrm{Bu}^{2}$, Wei $\mathrm{Li}^{1}{ }^{1}$, Bin $\mathrm{Shi}^{2} *$, Shengnan $\mathrm{Cao}^{2}$, Jianpeng $\mathrm{An}^{2}$, Xiangwei Meng ${ }^{1}$, Zhixiang $\mathrm{Ma}^{1}$, Leilei Dong ${ }^{1}$, Qinghao Zhang ${ }^{2}$, Tao Wang ${ }^{2}$

${ }^{1}$ Biomedical Engineering Institute, School of Control Science and Engineering, Shandong University, Jinan 250061, China

${ }^{2}$ Bone Biomechanics Engineering Laboratory of Shandong Province, Neck-Shoulder and Lumbocrural Pain Hospital of Shandong First Medical University, Shandong Medicinal Biotechnology Center, Shandong First Medical University \& Shandong Academy of Medical Sciences, Jinan 250062, China

*Corresponding author: Wei Li, Bin Shi

Wei Li:

Biomedical Engineering Institute, School of Control Science and Engineering, Shandong University, Jinan 250061, China

Tel: 086-531-88392824; Fax: 086-531-88392824

E-mail: cindy@sdu.edu.cn

Bin Shi:

Bone Biomechanics Engineering Laboratory of Shandong Province, Neck-Shoulder and Lumbocrural Pain Hospital of Shandong First Medical University, Shandong Medicinal Biotechnology Center, Shandong First Medical University \& Shandong Academy of Medical Sciences, Jingshi Road 18877, Jinan 250062, Shandong Province, China

Tel: +86-0531-82919760

E-mail: sdyky-shibin@163.com 


\section{Abstract}

Purpose: This paper was designed to critically provide empirical evidence for the relationship between temperature and intensity of back pain among people with lumbar disc herniation (LDH). Methods: Distributed lag linear and non-linear models (DLNM) was used to evaluate the relationship between lag-response and exposure to ambient temperature. Stratification was based on age and gender. Results: When daily average temperature was on the rage of $15-23 \square$, the risk of hospitalization was at the lowest level for men group. About below 10 $\square$, risk for male hospitalization could keep increase when lag day were during lag0-lag5 and lag20-lag28. 40<age $\leq 50$ group was little affected when they exposed to ambient temperature.

Keywords: temperature, low back pain, lumbar disc herniation, distributed lag linear and non-linear models 


\section{Introduction}

Low back pain (LBP) is one of the common diseases that affect severely people's health, which tends to occur among middle-aged and elderly people[1,2]. The prevalence of LBP increased with age, but remained unchanged at a certain age. The prevalence of LBP is increasing at an alarming rate in all age groups. It is reported that about $15 \%$ 20\% of adults had experienced back pain during one single year and 50\% to $80 \%$ experience at least one episode of back pain during their lifetime[3]. Survey conducted in a university in the south of China has shown that about $731 / 3770(19.39 \%)$ of all participants had chronic low back pain and more female students had chronic low back pain[4]. LBP is increasingly recognized as a serious, worldwide public health concern. One published research showed that back pain experienced by patients were the one of strongest factors associated with this insomnia, which seriously affected patient's quality of sleep[5]. In addition, there is accompanied with some neurological symptoms among LBP patients, such as radicular pain, radiculopathy and lumbar spinal stenosis[6, 7]. LBP has become one of the leading causes of years lived with disability in most countries and age groups[6]. It was predicted that low back pain prevalence and disability increased markedly over the past 25 years and would likely increase further with population aging[8]. 
Thus, determining the factors that could trigger the pain intensity are particularly crucial. It was suggested that there was an association between ambient temperature and the sensitivity and intensity of pain[9-11]. However, on the contrary, some previous research found that temperature didn't influence the pain's intensity and sensitivity[12-14]. Therefore, this primary purpose of this paper was designed to critically provide empirical evidence for the relationship between temperature and intensity of back pain among people with lumbar disc herniation (LDH).

\section{Method}

Data about patient's age, gender, diagnostic logout, admission time, discharge time, residence area and work area (residence area and work area were used to ensure research area) from 2016 to 2019, obtained from Neck-Shoulder and Lumbocrural Pain Hospital. Temperature data at the same period was attained from Shandong Environmental Protection Department. In our study, people with low back pain who were admitted to hospital and developed the lumbar disc herniation, were brought into this study, and were seen that the intensity of pain were acutely exacerbated.

Distributed lag linear and non-linear models (DLNM) describes the associations showing potentially non-linear and delayed effects in time series data, which has been widely used to evaluate the relationship 
between lag-response and exposure to ambient temperature[15-18].

DLNM was used to analyze the association between temperature and its lag-response for LDH patient's with back pain. The DLNM was presented as follow:

$$
\begin{gathered}
\log [\mathrm{E}(\mathrm{y})]=\alpha+\text { Temperature }+\mathrm{ns}(\text { time }, \mathrm{df})+\mathrm{ns}(\text { Humidity, } \mathrm{df})+ \\
\text { factor(DOW })+ \text { factor(Holiday })
\end{gathered}
$$

Where $\log [$.$] means connected function, \mathrm{E}(\mathrm{y})$ is the expected people who visited hospital, $\alpha$ is the constant term, Temperature represents the daily average temperature, time is the time variable, ns(.) represents natural cubic splines, df means the freedom of degree. DOW is the day of week, and Holiday is holiday variable. According to previous research, there was the lag effect of temperature on people's health, therefore, lag effect of daily average temperature was considered in this study[18, 19]. Stratification based on age and gender was also considered. All the statistical analyses above mentioned were finished in Rstudio software.

\section{Result}

\section{Descriptive result}

Table 1 describes the quartile of daily average temperature and relative humidity. The maximum and minimum of daily average temperature in Jinan during 2017-2019 were $33.4 \square$ and $-9.1 \square$, respectively. The $5 / 13$ 
maximum and minimum of relative humidity during research period were 14 and 98, respectively. Figure 1 presents the three-dimensional percentage bar chart based on age and gender. It can be found that in age $\leq 30$ group and $30<$ age $\leq 40$ group, the amount of men was more than that in women, while it was on the contrary among $40<$ age $\leq 50$, $50<$ age $\leq 60,60<$ age $\leq 70$ and age $>70$ group. Figure 2 and Figure 3 present the proportion of unhealthy habits and chronic diseases.

\section{DLNM Result}

The results of lag-response curve of temperature were set out in Figure 4. As can be seen clearly from the Figure 4, response to exposure to about $25-30 \square$ was different between men group and women group.

Figure 5 illustrates the effect of temperature on the hospitalization for LDH patients with back pain. When daily average temperature was on the rage of $15-23 \square$, the risk of hospitalization was at the lowest level for men group, while for women group, temperature was above $15 \square$, the risk was gradually decreased. From the contour plot of lag-response to temperature, when temperature was about below $10 \square$, risk for male hospitalization could keep increase when lag day were during lag0-lag5 and lag20-lag28, similarly, temperature was about over $21 \square$, lag effect would exacerbate the risk of hospitalization (Figure 6).

The three-dimension plots of lag-response to temperature based on 
stratification of age can be compared in Figure 7. Contour plots of lag-response to temperature based on the age stratification were displayed in Figure 8. What is striking about the Figure 8 is that $40<$ age $\leq 50$ group was little affected when they exposed to ambient temperature. The effect of temperature on the hospitalization when lag day was on 28. The effect of temperature on the hospitalization when lag day was on 28 was displayed on Figure 9.

\section{Discussion}

Lumbar disc herniation (LDH), which the early symptoms are low back pain, has a serious impact on people's quality of life[5, 20-23]. LDH patients usually take some medicine in their home to relieve their pain, including low back pain, while when intensity of pain was abruptly worsened, they would turn to hospital for relieving pain. In this paper, patients admitted to hospital, were seen that the pain aggravated. The aim of the present research was to examine the relationship between temperature and intensity of back pain among people with lumbar disc herniation (LDH).

In accordance with the present results, previous studies have demonstrated that there was a link between ambient temperature and the sensitivity and intensity of pain, which means that temperature could aggravate back pain[9, 10, 24]. The finding that the proportion of 
unhealthy habits, drinking and smoking were $5.9 \%$ and $7.8 \%$, respectively, which confirmed that previous report that patients with smoking and alcohol abuse had a relative risk of 4.489 and 3.326 for low back pain, respectively, compared with patients without the defined risk factor[25]. Other studies also shown that alcohol use and tobacco use appeared to have a significant relationship with low back pain[23, 26, 27]. We also found that about $16 \%$ patients with hypertension, which could provide the evidence that there was the association between hypertension and the prevalence of low back pain[28, 29]. About 6\% LBH patients developed the diabetes, which could hint that there might be the link between diabetes and low back pain.[30, 31].

However, some reported previous studies in this field have demonstrated the conflicting results. The reasons which might account for this phenomenon were as follows. Simple correlation was used to evaluate their relationship, but this method reflects the relationship at the same period and neglect the delay effect. On the other hand, some noisy data might influence the result.

The limitation of this study was that we didn't consider the condition which patients took medicine, as we mentioned above, some LDH patients developed diabetes, hypertension and so on, these could also affect this research. On the other hand, the work category of patients was not considered, we focused on the effect of temperature on low back pain 
among LDH patients. The future work was to investigate the impact of temperature and relative humidity on low back pain during different seasons.

\section{Ethical approval}

This study was approved by the ethics committee of the Biomedical Engineering Institute, School of Control Science and Engineering, Shandong University. All procedures performed in studies involving human participants were in accordance with the ethical standards of the institutional and/or national research committee and with the 1964 Helsinki declaration and its later amendments or comparable ethical standards.

\section{Acknowledgements}

This study was supported in part by grants from the National Natural Science Foundation (\#21728701), the Ministry of Education postdoctoral fund (\#2015M572044), Shandong Province Science and Technology Development Project (\#GG201709260070), the Distinguished Experts of Taishan Scholar Project (grant number ts201511074), China Postdoctoral Science Foundation (grant number 2019M662420), Natural Science Foundation of Shandong Province (grant number ZR2019MH134), Academic Promotion Project of Shandong First Medical University (grant $9 / 13$ 


\title{
number 2019QL003), Science and Technology Development Program of
}

\author{
Shandong Academy of Medical Sciences (grant number 2018-23).
}

\section{Conflicts of Interest}

The authors declare that they have no conflicts of interest.

\section{References:}

[1]. Manchikanti, L., et al., Epidemiology of low back pain in adults. Neuromodulation, 2014. 17 Suppl 2: p. 3-10.

[2]. Claus, M., et al., Prevalence of back pain in employees of a German chemical company: results of a large cross-sectional study. J Occup Med Toxicol, 2019. 14: p. 16.

[3]. Rubin, D.I., Epidemiology and risk factors for spine pain. Neurol Clin, 2007. 25(2): p. 353-71.

[4]. Tong, F., et al., An epidemiological study of the prevalence rate of inflammatory back pain and axial spondyloarthritis in a university in the south of China. Clin Rheumatol, 2018. 37(11): p. 3087-3091.

[5]. Bahouq, H., et al., Prevalence and severity of insomnia in chronic low back pain patients. Rheumatol Int, 2013. 33(5): p. 1277-81.

[6]. Hartvigsen, J., et al., What low back pain is and why we need to pay attention. Lancet, 2018. 391(10137): p. 2356-2367.

[7]. Chiu, C.C., et al., The probability of spontaneous regression of lumbar herniated disc: a systematic review. Clin Rehabil, 2015. 29(2): p. 184-95.

[8]. Hurwitz, E.L., et al., The Global Spine Care Initiative: a summary of the global burden of low back and neck pain studies. Eur Spine J, 2018. 27(Suppl 6): p. 796-801.

[9]. McGorry, R.W., et al., Meteorological conditions and self-report of low back pain. Spine (Phila Pa 1976), 1998. 23(19): p. 2096-102; discussion 2103.

[10]. Duong, V., et al., Does weather affect daily pain intensity levels in patients with acute low back pain? A prospective cohort study. Rheumatology International, 2016. 36(5): p. 679-684.

[11]. Timmermans, E.J., et al., Self-perceived weather sensitivity and joint pain in older people with osteoarthritis in six european countries: Results from the European Project on OSteoArthritis (EPOSA). European Geriatric Medicine, 2013. 4: p. S24.

[12]. Beilken, K., et al., Acute Low Back Pain? Do Not Blame the Weather-A Case-Crossover Study. Pain Medicine, 2016: p. pnw126.

[13]. Duong, V., et al., Does weather affect daily pain intensity levels in patients with acute low back pain? A prospective cohort study. Rheumatology International, 2016. 36(5): p. 679-684.

[14]. Ferreira, M.L., et al., The influence of weather on the risk of pain exacerbation in patients with knee osteoarthritis - a case-crossover study. Osteoarthritis and Cartilage, 2016. 24(12): p. 2042-2047.

[15]. Gasparrini, A., Distributed Lag Linear and Non-Linear Models in R: The Package dlnm. J Stat Softw, 2011. 43(8): p. 1-20.

[16]. Chien, L.C., et al., Considering spatial heterogeneity in the distributed lag non-linear model when

$10 / 13$ 
analyzing spatiotemporal data. J Expo Sci Environ Epidemiol, 2018. 28(1): p. 13-20.

[17]. Marinaccio, A., et al., Nationwide epidemiological study for estimating the effect of extreme outdoor temperature on occupational injuries in Italy. Environ Int, 2019. 133(Pt A): p. 105176.

[18].Zhan, Z.Y., et al., Effects of ambient temperature on ambulance emergency call-outs in the subtropical city of Shenzhen, China. PLoS One, 2018. 13(11): p. e0207187.

[19]. Chen, C., et al., Risk of temperature, humidity and concentrations of air pollutants on the hospitalization of AECOPD. PLoS One, 2019. 14(11): p. e0225307.

[20]. van der Windt, D.A., et al., Physical examination for lumbar radiculopathy due to disc herniation in patients with low-back pain. Cochrane Database Syst Rev, 2010(2): p. CD007431.

[21]. Telli, H., B. Huner and O. Kuru, Determination of the Prevalence from Clinical Diagnosis of Sacroiliac Joint Dysfunction in Patients with Lumbar Disc Hernia and an Evaluation of the Effect of this Combination on Pain and Quality of Life. Spine (Phila Pa 1976), 2019.

[22]. Waterman, B.R., P.J. Belmont and A.J. Schoenfeld, Low back pain in the United States: incidence and risk factors for presentation in the emergency setting. Spine J, 2012. 12(1): p. 63-70.

[23]. Yang, H. and S. Haldeman, Behavior-Related Factors Associated With Low Back Pain in the US Adult Population. Spine (Phila Pa 1976), 2018. 43(1): p. 28-34.

[24]. Xiong, G., et al., Factor analysis on symptoms and signs of chronic low-back pain based on Traditional Chinese Medicine theory. J Altern Complement Med, 2011. 17(1): p. 51-5.

[25]. Shemory, S.T., K.J. Pfefferle and I.M. Gradisar, Modifiable Risk Factors in Patients With Low Back Pain. Orthopedics, 2016. 39(3): p. e413-6.

[26]. Shiri, R., et al., The association between smoking and low back pain: a meta-analysis. Am J Med, 2010. 123(1): p. 87.e7-35.

[27]. Leboeuf-Yde, C., Smoking and low back pain. A systematic literature review of 41 journal articles reporting 47 epidemiologic studies. Spine (Phila Pa 1976), 1999. 24(14): p. 1463-70.

[28]. Bae, Y.H., et al., Association between Hypertension and the Prevalence of Low Back Pain and Osteoarthritis in Koreans: A Cross-Sectional Study. PLoS One, 2015. 10(9): p. e0138790.

[29]. Heuch, I., et al., Does high blood pressure reduce the risk of chronic low back pain? The Nord-Trondelag Health Study. Eur J Pain, 2014. 18(4): p. 590-8.

[30]. Dario, A., et al., Mapping the association between back pain and type 2 diabetes: A cross-sectional and longitudinal study of adult Spanish twins. PLoS One, 2017. 12(4): p. e0174757.

[31]. Heuch, I., et al., Does diabetes influence the probability of experiencing chronic low back pain? A population-based cohort study: the Nord-Trondelag Health Study. BMJ Open, 2019. 9(9): p. e031692. 
medRxiv preprint doi: https://doi.org/10.1101/2020.01.15.20017558; this version posted January 18, 2020. The copyright holder for this preprint (which was not certified by peer review) is the author/funder, who has granted medRxiv a license to display the preprint in perpetuity.

All rights reserved. No reuse allowed without permission.

Table 1. Quartile of daily average temperature and relative humidity

\begin{tabular}{llllll}
\hline & Min & $\mathrm{P}_{25}$ & $\mathrm{P}_{50}$ & $\mathrm{P}_{75}$ & Max \\
\hline Temperature & -9.1 & 6 & 16.5 & 25.3 & 33.4 \\
Humidity & 14 & 36 & 48 & 64.75 & 98 \\
\hline
\end{tabular}

Min: minimum; Max: maximum; P25: the first quartile; P50: the second quartile; P75: the third quartile; 


\section{Figure Legends}

Figure 1 Three-dimensional percentage bar chart of age and gender

Figure 2The proportion of chronic disease among whole amount

Figure 3 The proportion of unhealthy habits among whole amount

Figure 4 Three-dimensional lag-response curve of temperature (A: whole;

B: Men; C: Women)

Figure 5 The effect of temperature on the hospitalization when lag day was on 28 (A: whole; B: Men; C: Women)

Figure 6 Contour plot of lag-response about temperature on hospitalization (A: whole; B: men; C: women)

Figure 7 The three-dimension of lag-response to temperature based on stratification of age (A: age $\leq 30$ group; B: $30<$ age $\leq 40$ group; C:40<age $\leq 50 ;$ D:50<age $\leq 60 ; \mathrm{E}: 60<$ age $\leq 70 ; \mathrm{F}:$ age $>70$ group)

Figure 8 Contour plots of lag-response to temperature based on the age stratification (A: age $\leq 30$ group; B: $30<$ age $\leq 40$ group; C: $40<$ age $\leq 50$; D:50<age $\leq 60$; E: $60<$ age $\leq 70 ; \mathrm{F}:$ age $>70$ group)

Figure 9 The effect of temperature on the hospitalization when lag day was on 28 (A: age $\leq 30$ group; B: $30<$ age $\leq 40$ group; C:40<age $\leq 50$; D:50<age $\leq 60$; E: $60<$ age $\leq 70 ;$ F: age $>70$ group) 
medRxiv preprint doi: https://doi.org/10.1101/2020.01.15.20017558; this version posted January 18, 2020. The copyright holder for this preprint (which was not certified by peer review) is the author/funder, who has granted medRxiv a license to display the preprint in perpetuity.

All rights reserved. No reuse allowed without permission.

$\triangle$ Male i Female

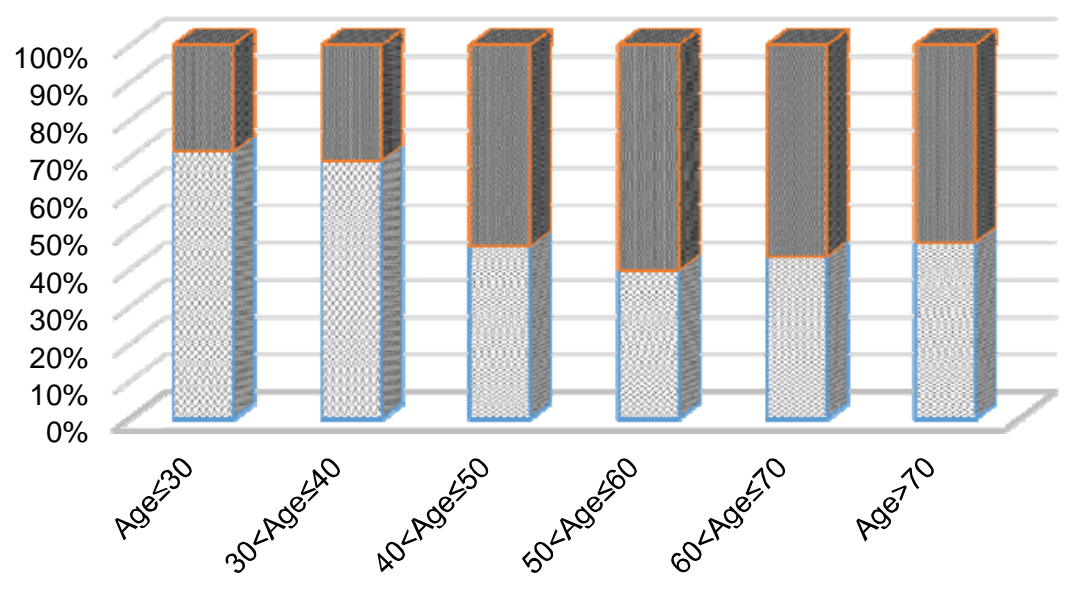

Figure 1

Figure 1 Three-dimensional percentage bar chart of age and gender 
medRxiv preprint doi: https://doi.org/10.1101/2020.01.15.20017558; this version posted January 18, 2020. The copyright holder for this preprint (which was not certified by peer review) is the author/funder, who has granted medRxiv a license to display the preprint in perpetuity.

All rights reserved. No reuse allowed without permission.

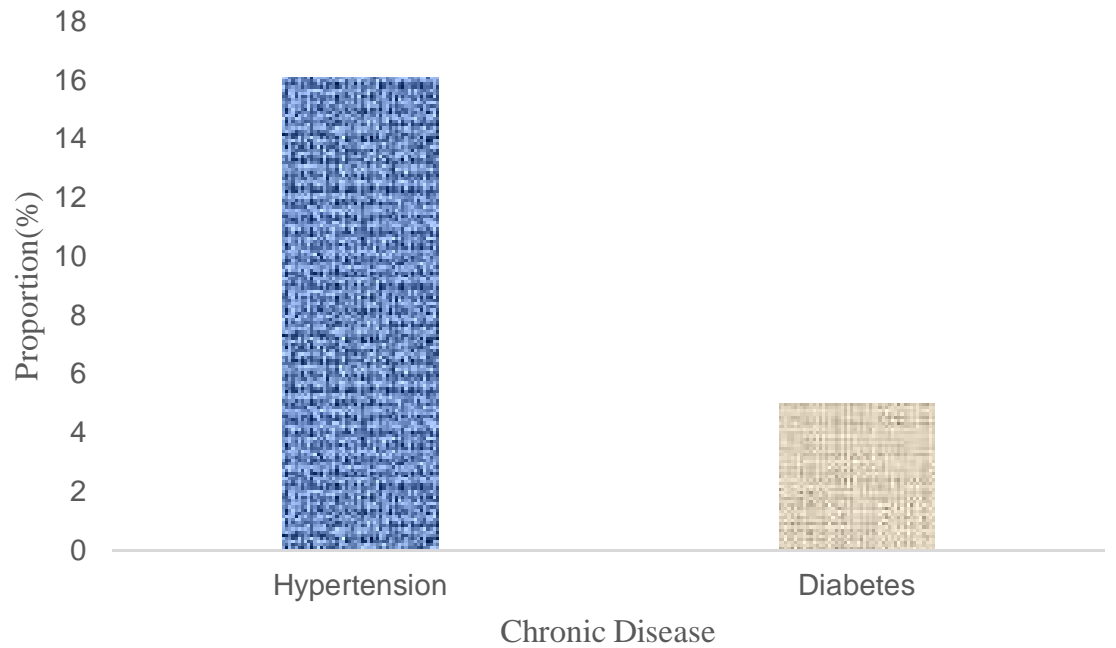

Figure 2 The proportion of chronic disease among whole amount 
medRxiv preprint doi: https://doi.org/10.1101/2020.01.15.20017558; this version posted January 18, 2020. The copyright holder for this preprint (which was not certified by peer review) is the author/funder, who has granted medRxiv a license to display the preprint in perpetuity.

All rights reserved. No reuse allowed without permission.

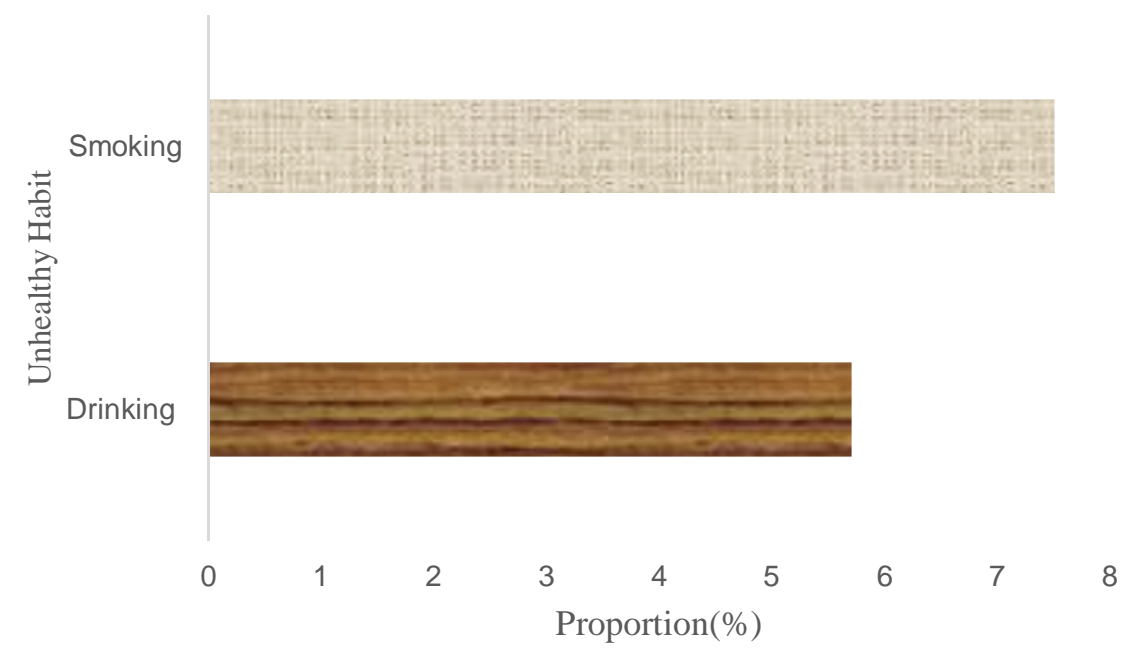

Figure 3 The proportion of unhealthy habits among whole amount 
medRxiv preprint doi: https://doi.org/10.1101/2020.01.15.20017558; this version posted January 18,2020 . The copyright holder for this preprint (which was not certified by peer review) is the author/funder, who has granted medRxiv a license to display the preprint in perpetuity.

All rights reserved. No reuse allowed without permission.

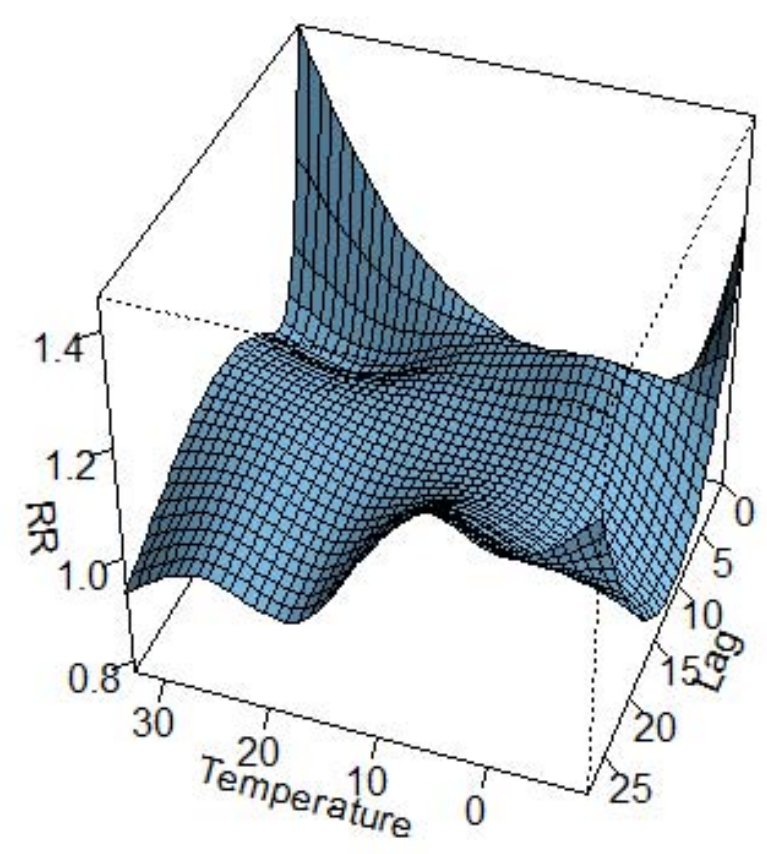

Figure 4A 
medRxiv preprint doi: https://doi.org/10.1101/2020.01.15.20017558; this version posted January 18,2020 . The copyright holder for this preprint (which was not certified by peer review) is the author/funder, who has granted medRxiv a license to display the preprint in perpetuity.

All rights reserved. No reuse allowed without permission.

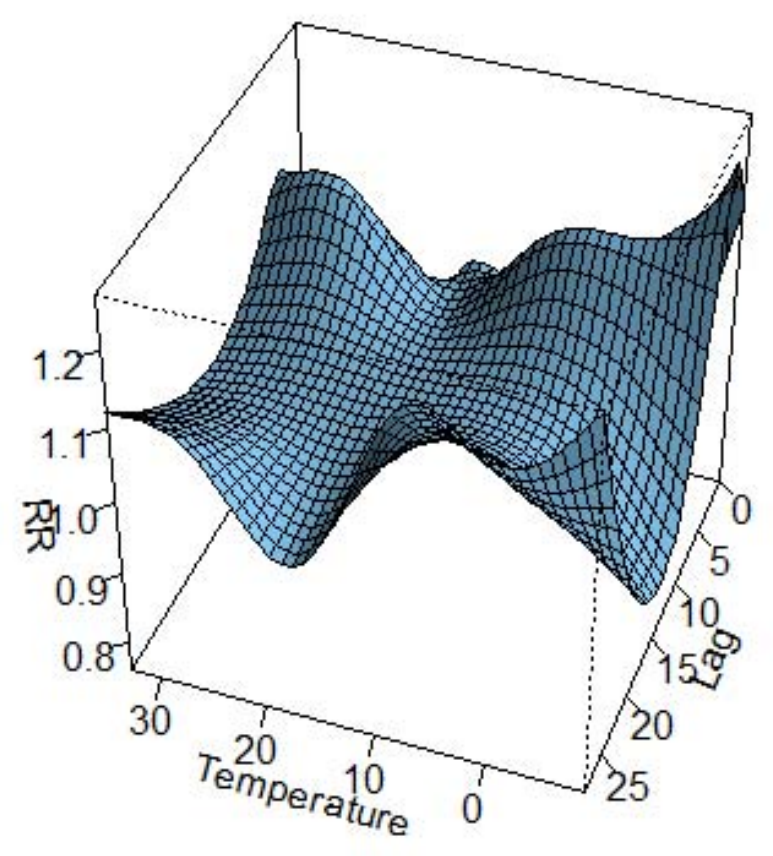

Figure 4B 
medRxiv preprint doi: https://doi.org/10.1101/2020.01.15.20017558; this version posted January 18, 2020. The copyright holder for this preprint (which was not certified by peer review) is the author/funder, who has granted medRxiv a license to display the preprint in perpetuity.

All rights reserved. No reuse allowed without permission.

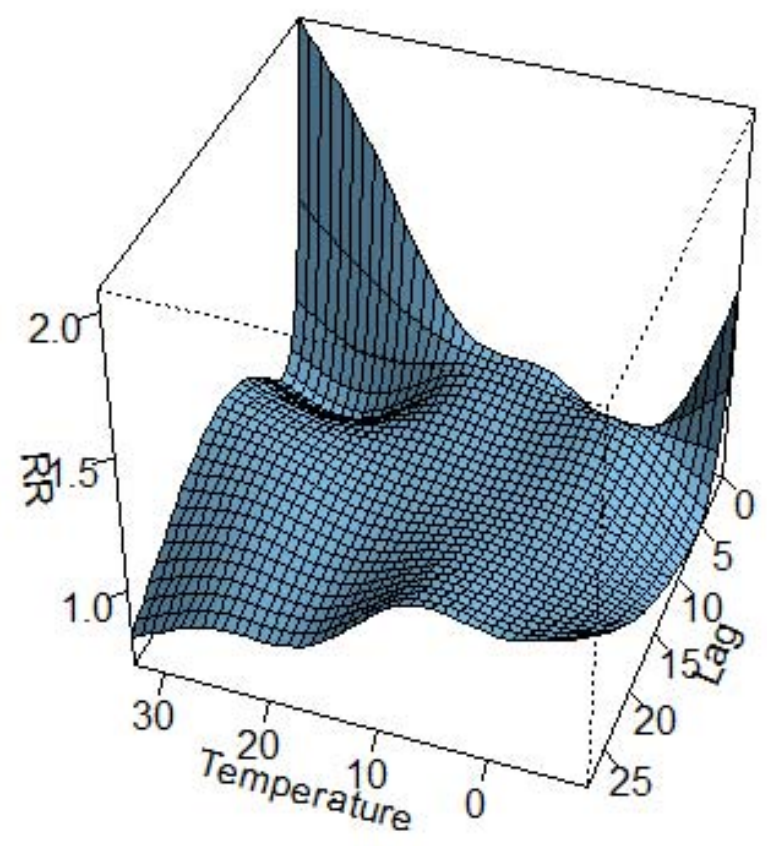

Figure4C

Figure 4 Three-dimensional lag-response curve of temperature (A: whole; B: Men; C: Women) $R R$ : relative risk; 
medRxiv preprint doi: https://doi.org/10.1101/2020.01.15.20017558; this version posted January 18, 2020. The copyright holder for this preprint (which was not certified by peer review) is the author/funder, who has granted medRxiv a license to display the preprint in perpetuity.

All rights reserved. No reuse allowed without permission.

\section{Lag Day=28}

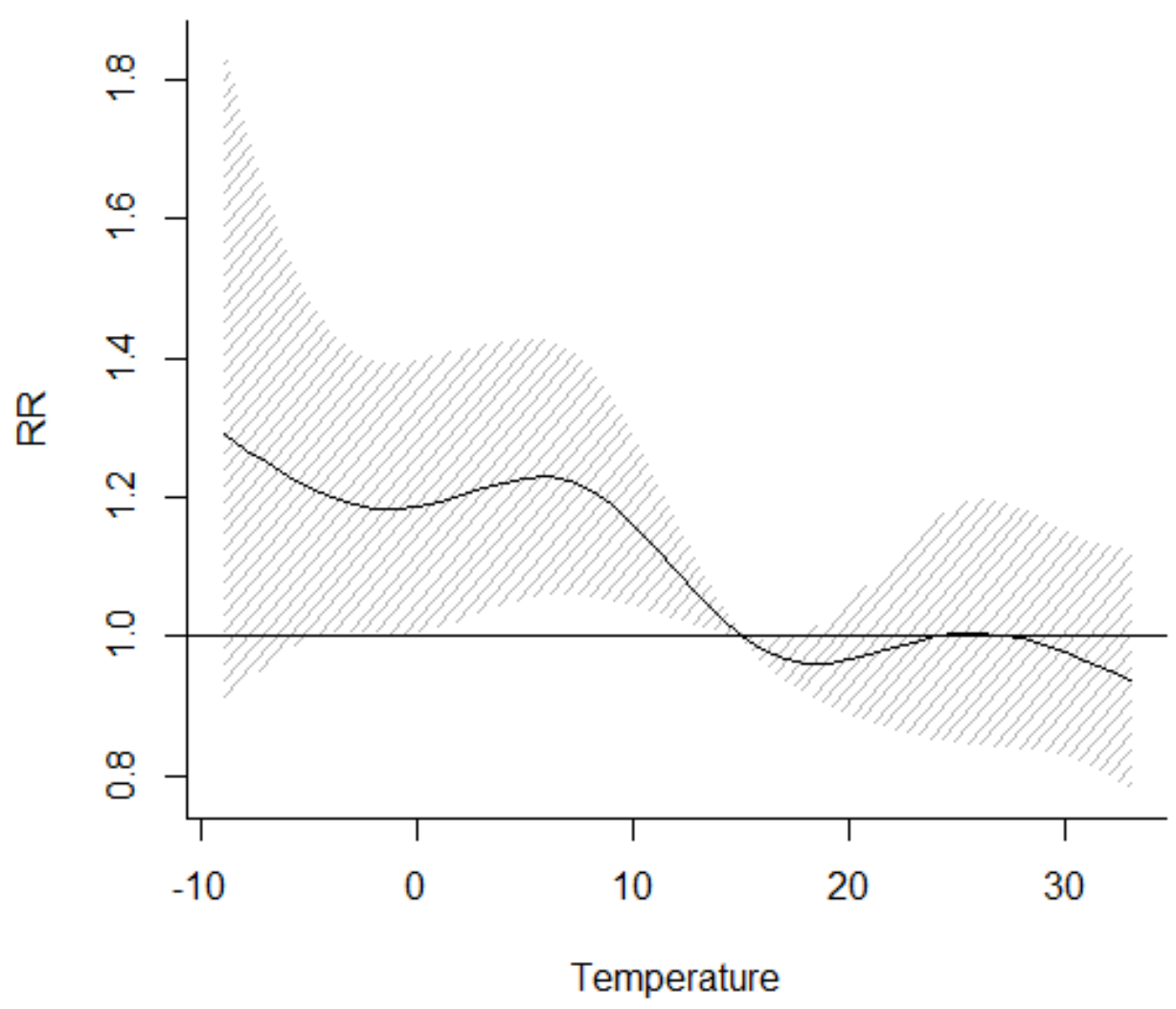

Figure 5A 
medRxiv preprint doi: https://doi.org/10.1101/2020.01.15.20017558; this version posted January 18, 2020. The copyright holder for this preprint (which was not certified by peer review) is the author/funder, who has granted medRxiv a license to display the preprint in perpetuity.

All rights reserved. No reuse allowed without permission.

\section{Lag Day=28}

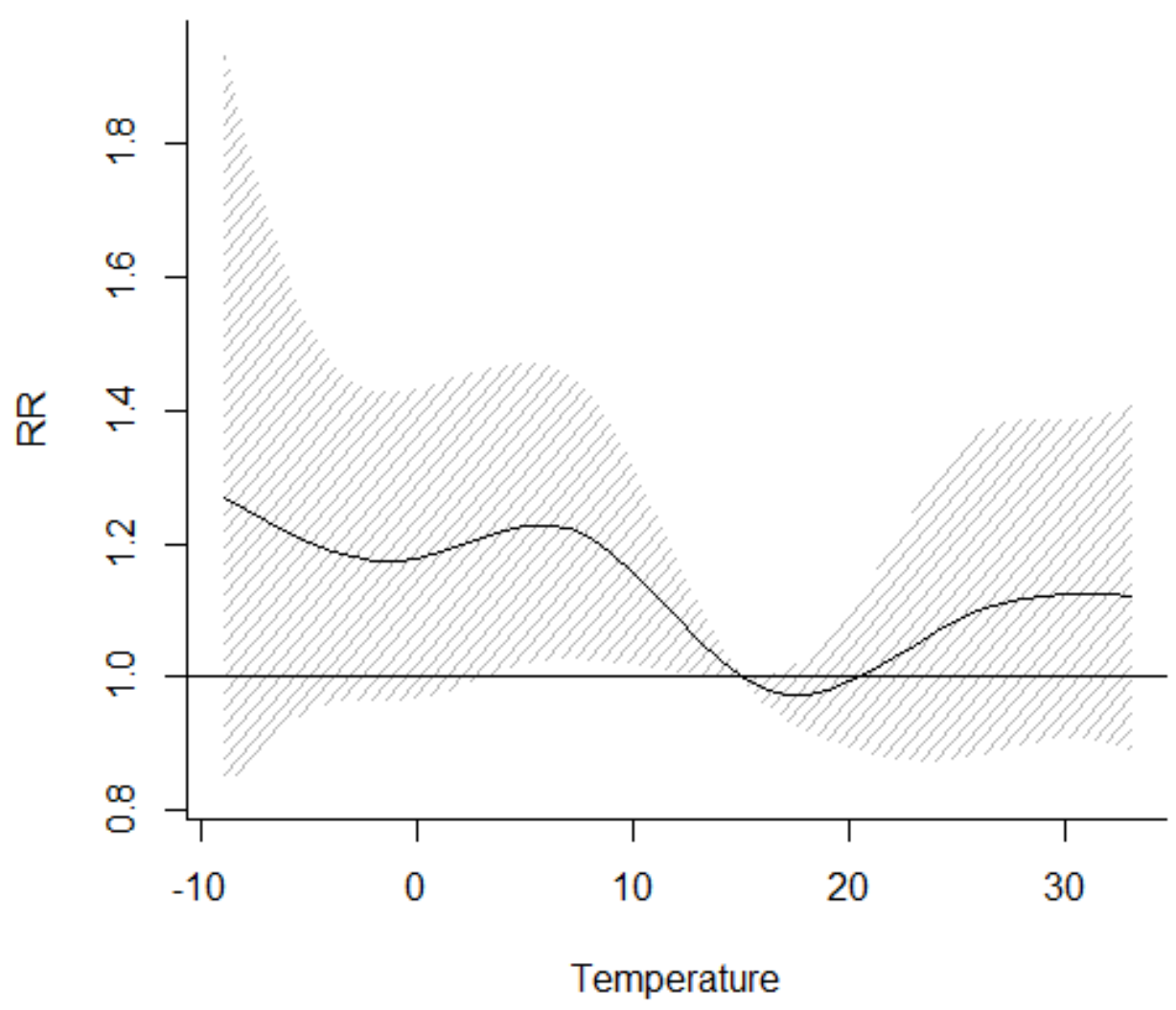

Figure 5B 


\section{Lag Day=28}

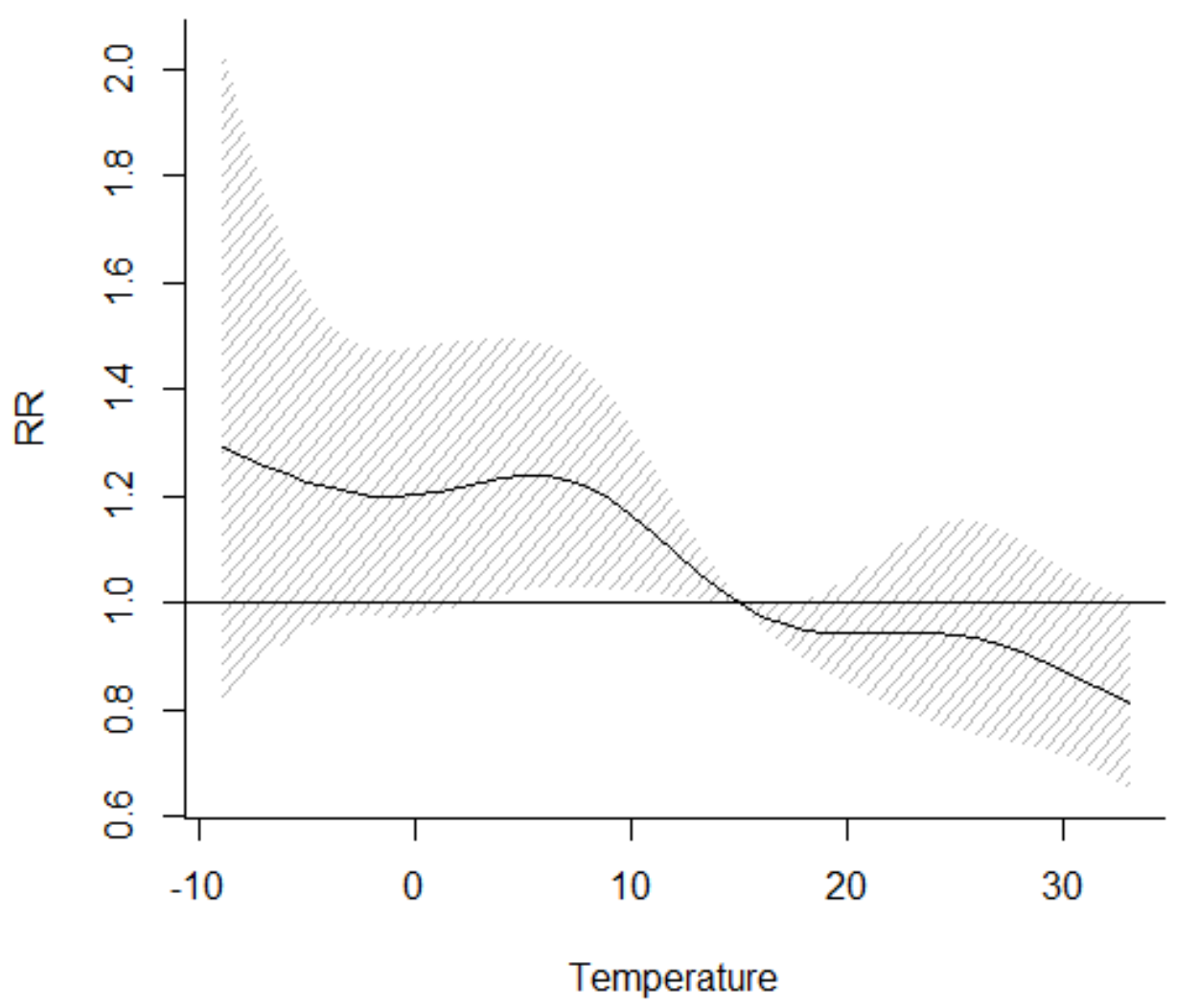

Figure 5C

Figure 5 The effect of temperature on the hospitalization when lag day was on 28 (A: whole; B:

Men; C: Women)

RR: relative risk 
medRxiv preprint doi: https://doi.org/10.1101/2020.01.15.20017558; this version posted January 18, 2020. The copyright holder for this preprint (which was not certified by peer review) is the author/funder, who has granted medRxiv a license to display the preprint in perpetuity. All rights reserved. No reuse allowed without permission.

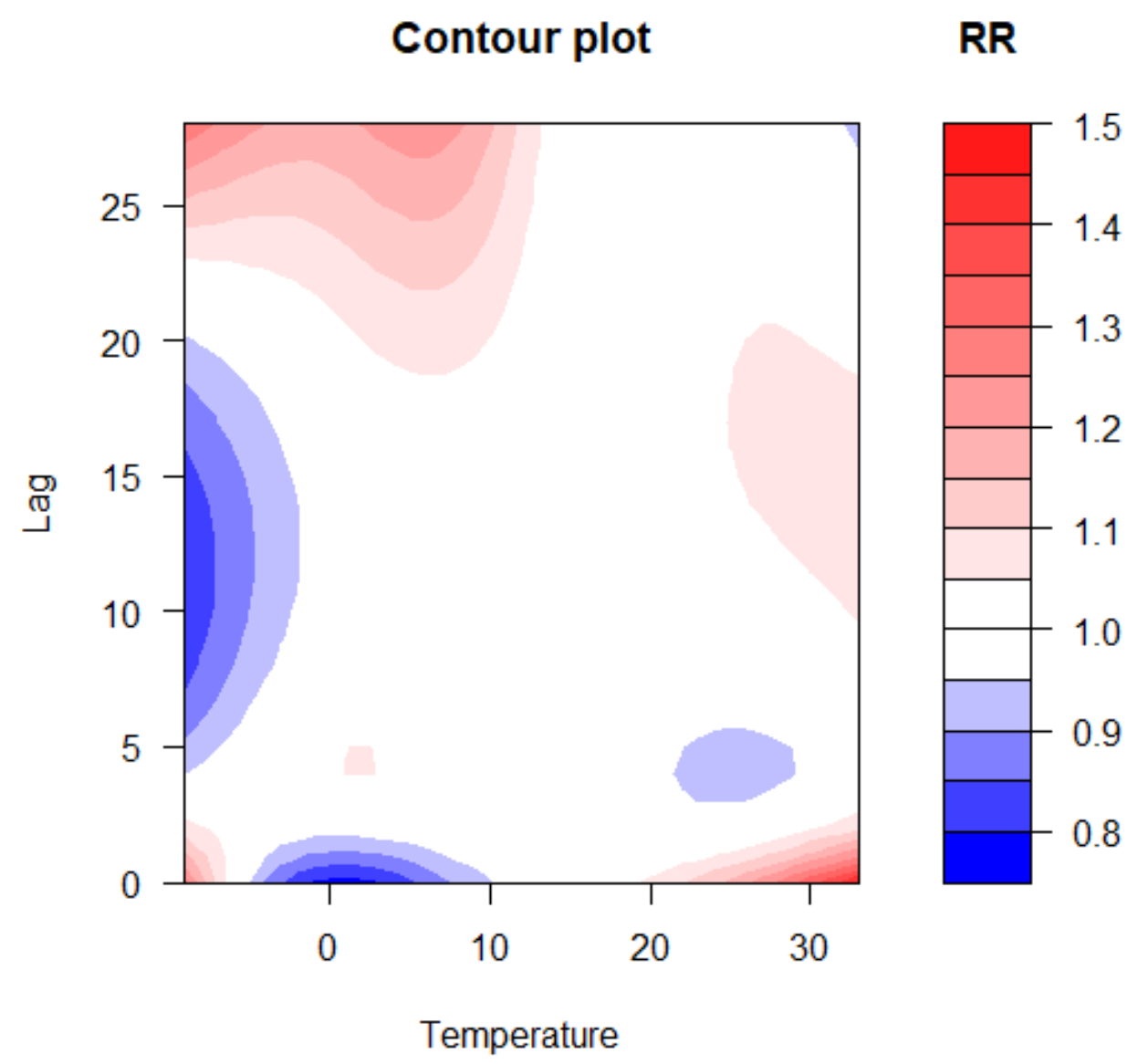

Figure 6A 
medRxiv preprint doi: https://doi.org/10.1101/2020.01.15.20017558; this version posted January 18, 2020. The copyright holder for this preprint (which was not certified by peer review) is the author/funder, who has granted medRxiv a license to display the preprint in perpetuity.

All rights reserved. No reuse allowed without permission.

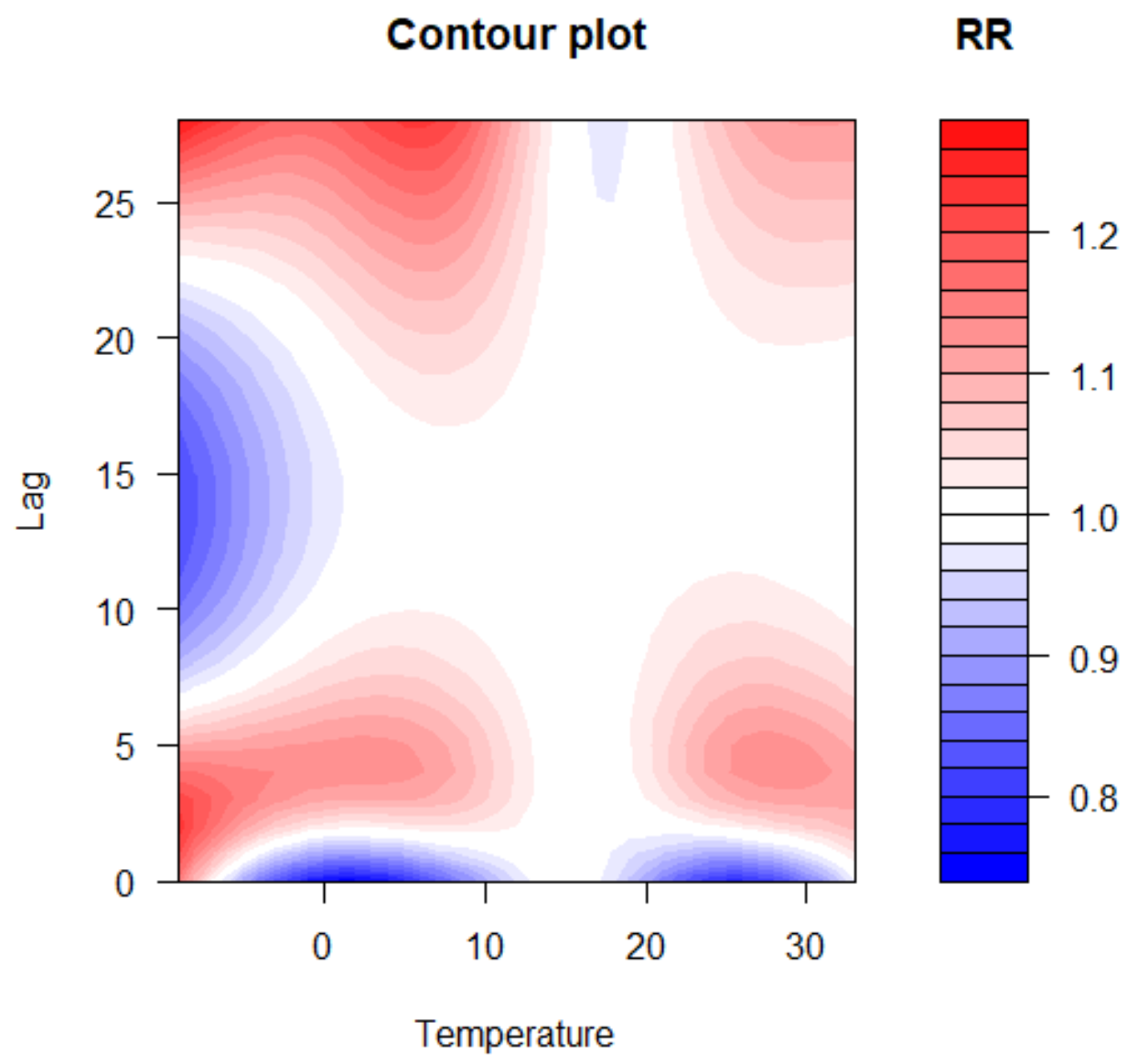

Figure 6B 
medRxiv preprint doi: https://doi.org/10.1101/2020.01.15.20017558; this version posted January 18, 2020. The copyright holder for this preprint (which was not certified by peer review) is the author/funder, who has granted medRxiv a license to display the preprint in perpetuity.

All rights reserved. No reuse allowed without permission.

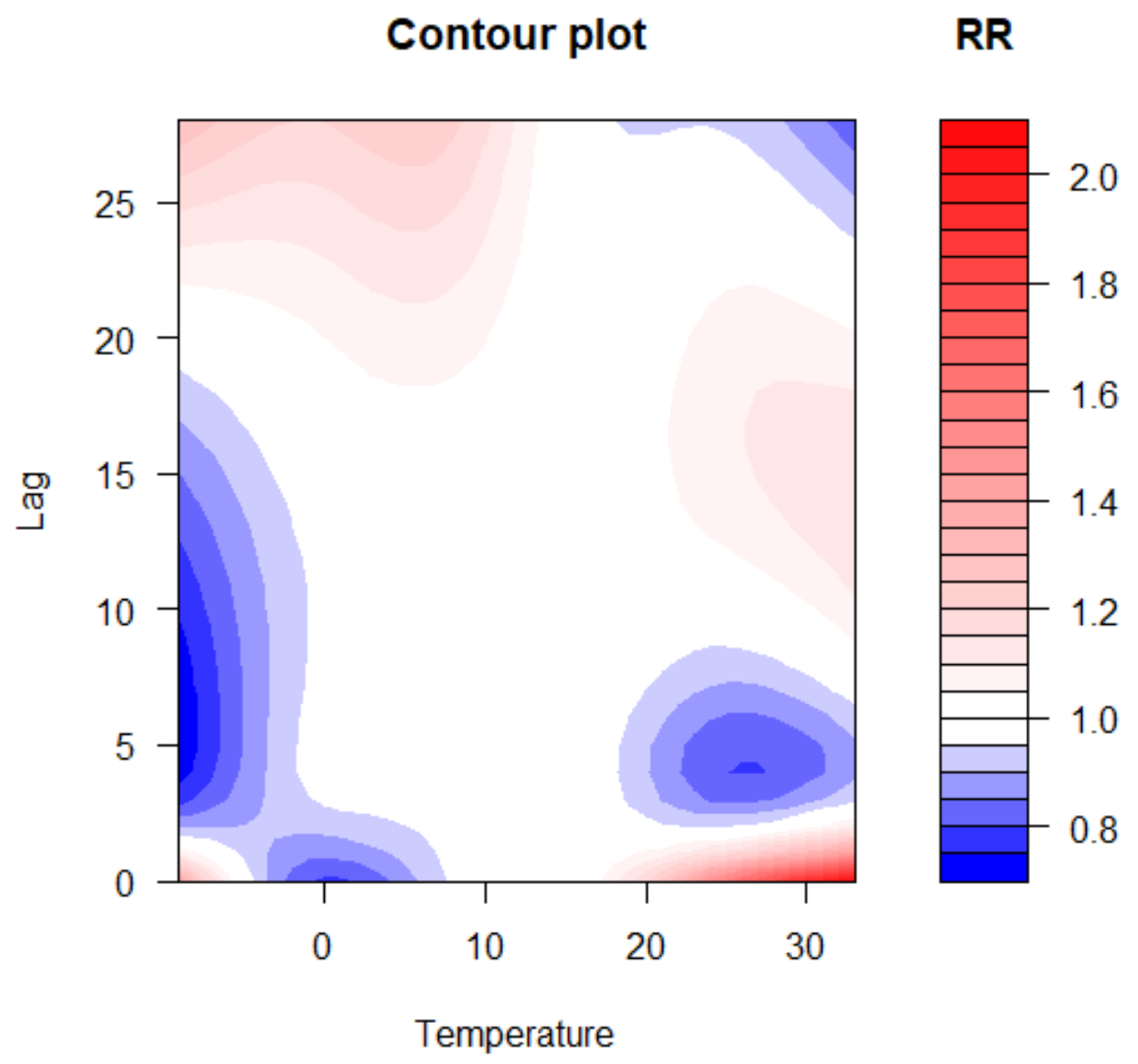

Figure 6C

Figure 6 Contour plot of lag-response about temperature on hospitalization (A: whole; B:men;

$\mathrm{C}$ : women) RR: relative risk 
medRxiv preprint doi: https://doi.org/10.1101/2020.01.15.20017558; this version posted January 18, 2020. The copyright holder for this preprint (which was not certified by peer review) is the author/funder, who has granted medRxiv a license to display the preprint in perpetuity.

All rights reserved. No reuse allowed without permission.

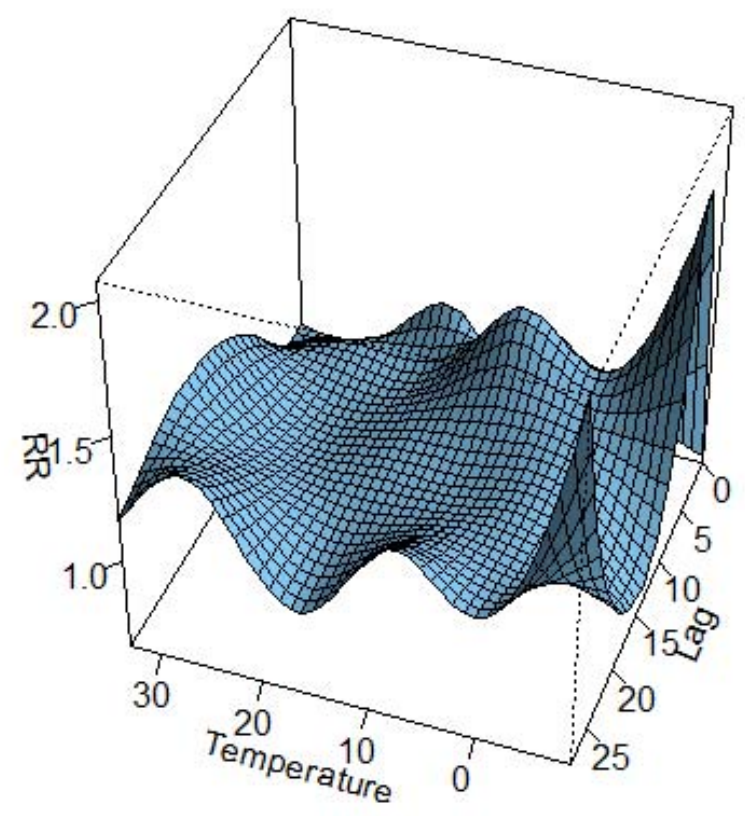

Figure 7A 
medRxiv preprint doi: https://doi.org/10.1101/2020.01.15.20017558; this version posted January 18,2020 . The copyright holder for this preprint (which was not certified by peer review) is the author/funder, who has granted medRxiv a license to display the preprint in perpetuity.

All rights reserved. No reuse allowed without permission.

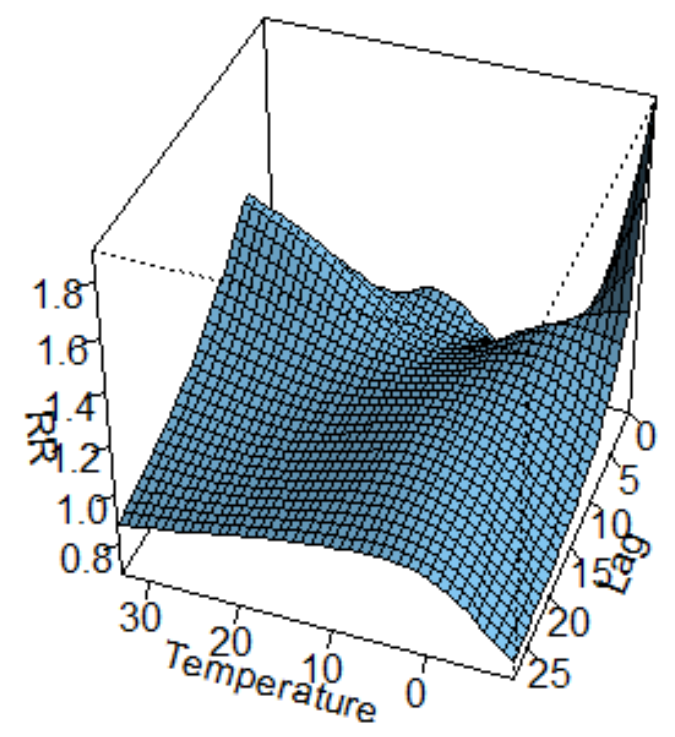

Figure 7B 
medRxiv preprint doi: https://doi.org/10.1101/2020.01.15.20017558; this version posted January 18, 2020. The copyright holder for this preprint (which was not certified by peer review) is the author/funder, who has granted medRxiv a license to display the preprint in perpetuity.

All rights reserved. No reuse allowed without permission.

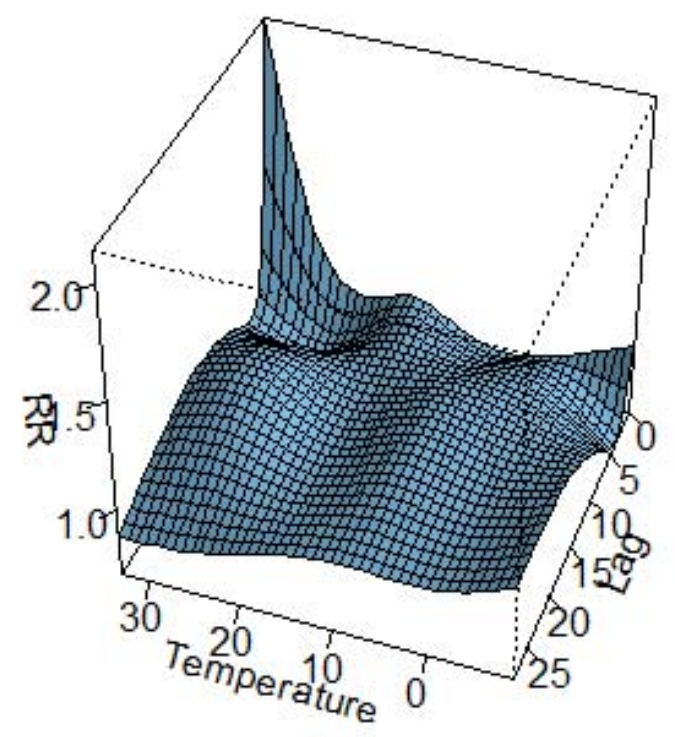

Figure 7C 
medRxiv preprint doi: https://doi.org/10.1101/2020.01.15.20017558; this version posted January 18, 2020. The copyright holder for this preprint (which was not certified by peer review) is the author/funder, who has granted medRxiv a license to display the preprint in perpetuity.

All rights reserved. No reuse allowed without permission.

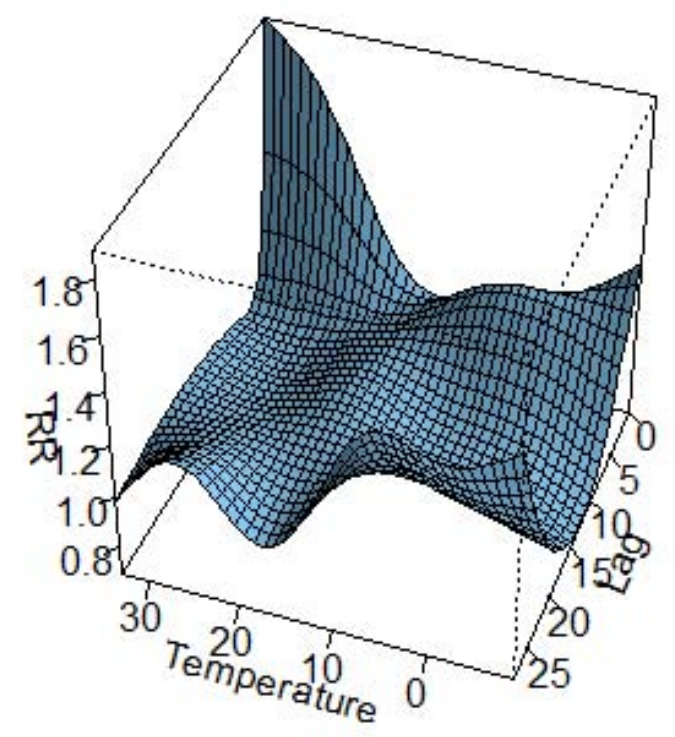

Figure 7D 
medRxiv preprint doi: https://doi.org/10.1101/2020.01.15.20017558; this version posted January 18, 2020. The copyright holder for this preprint (which was not certified by peer review) is the author/funder, who has granted medRxiv a license to display the preprint in perpetuity.

All rights reserved. No reuse allowed without permission.

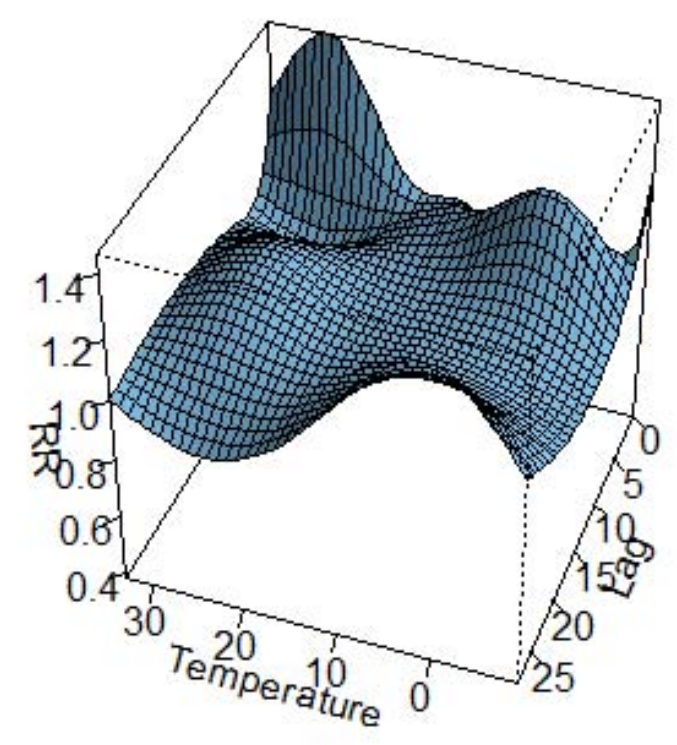

Figure 7E 
medRxiv preprint doi: https://doi.org/10.1101/2020.01.15.20017558; this version posted January 18, 2020. The copyright holder for this preprint (which was not certified by peer review) is the author/funder, who has granted medRxiv a license to display the preprint in perpetuity. All rights reserved. No reuse allowed without permission.

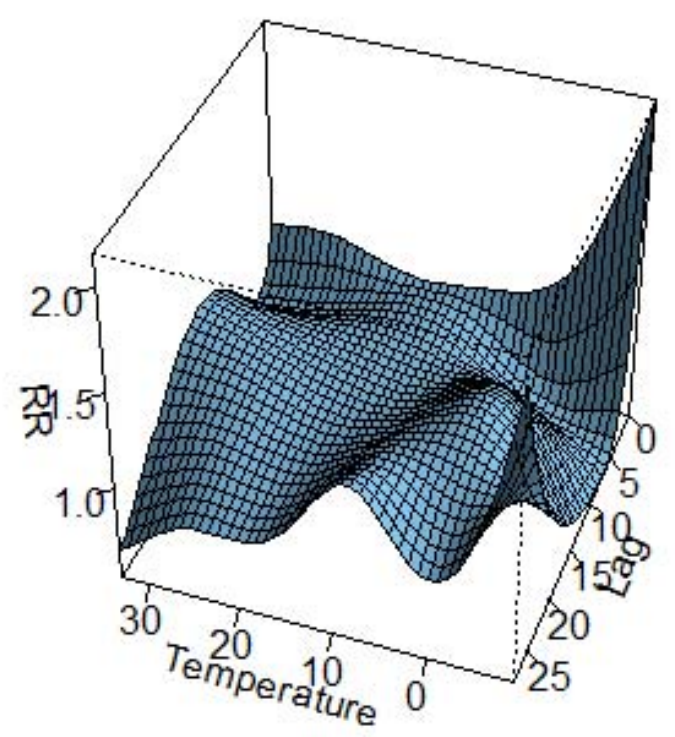

Figure 7F

Figure 7 The three-dimension of lag-response to temperature based on stratification of age (A: age $\leq 30$ group; B: $30<$ age $\leq 40$ group; C:40<age $\leq 50 ;$ D:50<age $\leq 60 ; \mathrm{E}: 60<$ age $\leq 70 ; \mathrm{F}:$ age $>70$ group) 
medRxiv preprint doi: https://doi.org/10.1101/2020.01.15.20017558; this version posted January 18, 2020. The copyright holder for this preprint (which was not certified by peer review) is the author/funder, who has granted medRxiv a license to display the preprint in perpetuity.

All rights reserved. No reuse allowed without permission.

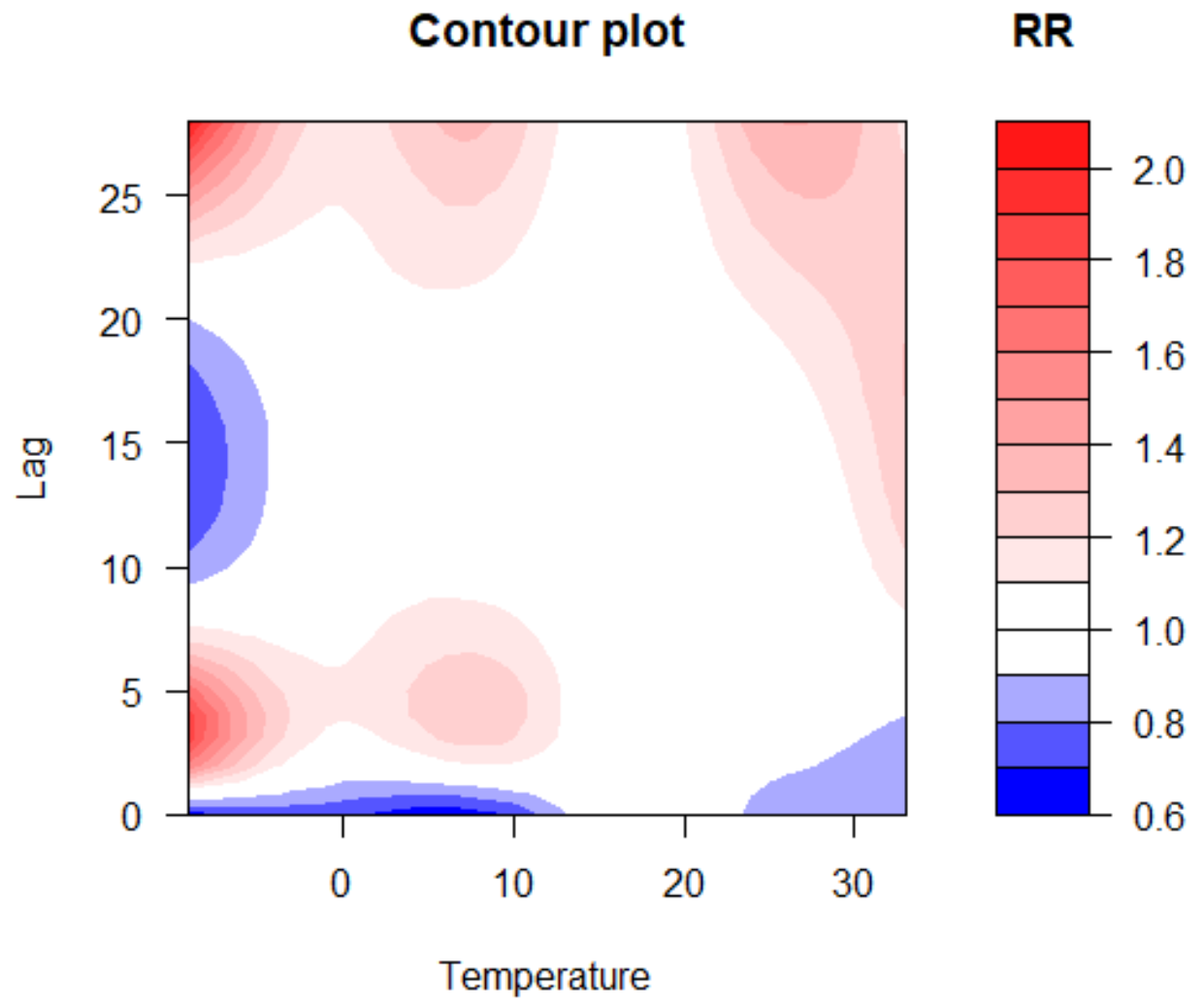

Figure 8A 
medRxiv preprint doi: https://doi.org/10.1101/2020.01.15.20017558; this version posted January 18, 2020. The copyright holder for this preprint (which was not certified by peer review) is the author/funder, who has granted medRxiv a license to display the preprint in perpetuity.

All rights reserved. No reuse allowed without permission.

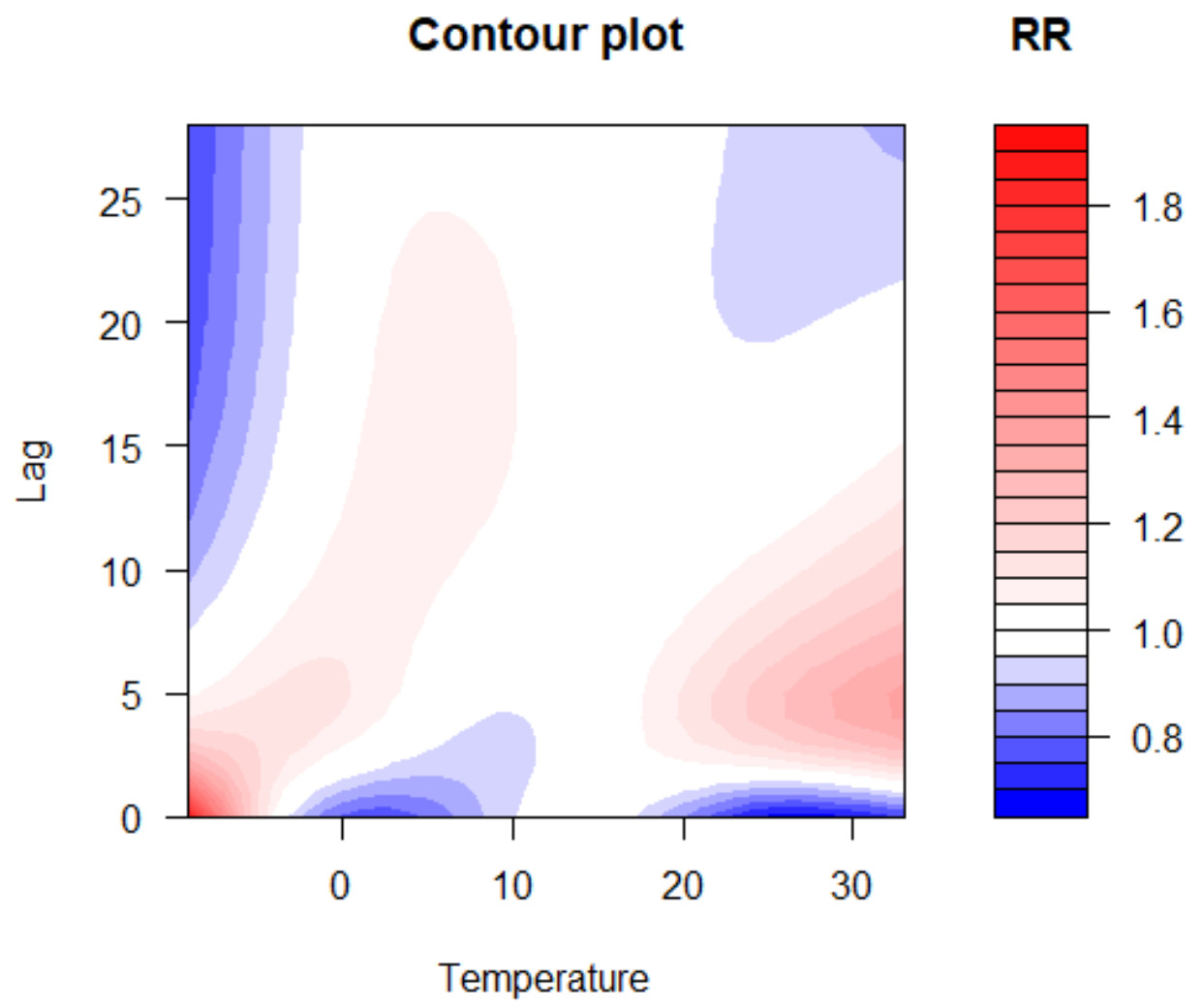

Figure 8B 
medRxiv preprint doi: https://doi.org/10.1101/2020.01.15.20017558; this version posted January 18, 2020. The copyright holder for this preprint (which was not certified by peer review) is the author/funder, who has granted medRxiv a license to display the preprint in perpetuity.

All rights reserved. No reuse allowed without permission.

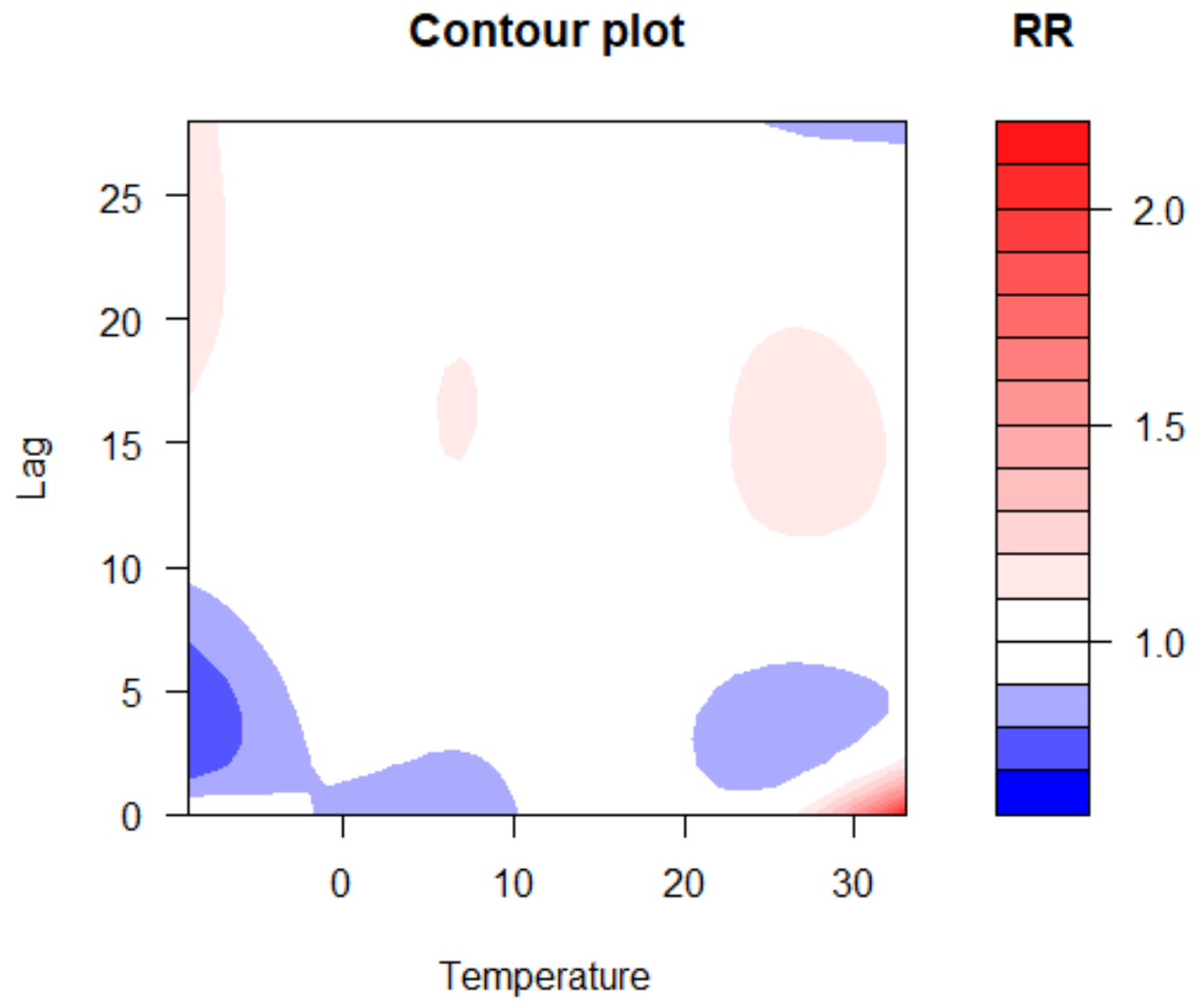

Figure 8C 
medRxiv preprint doi: https://doi.org/10.1101/2020.01.15.20017558; this version posted January 18, 2020. The copyright holder for this preprint (which was not certified by peer review) is the author/funder, who has granted medRxiv a license to display the preprint in perpetuity.

All rights reserved. No reuse allowed without permission.

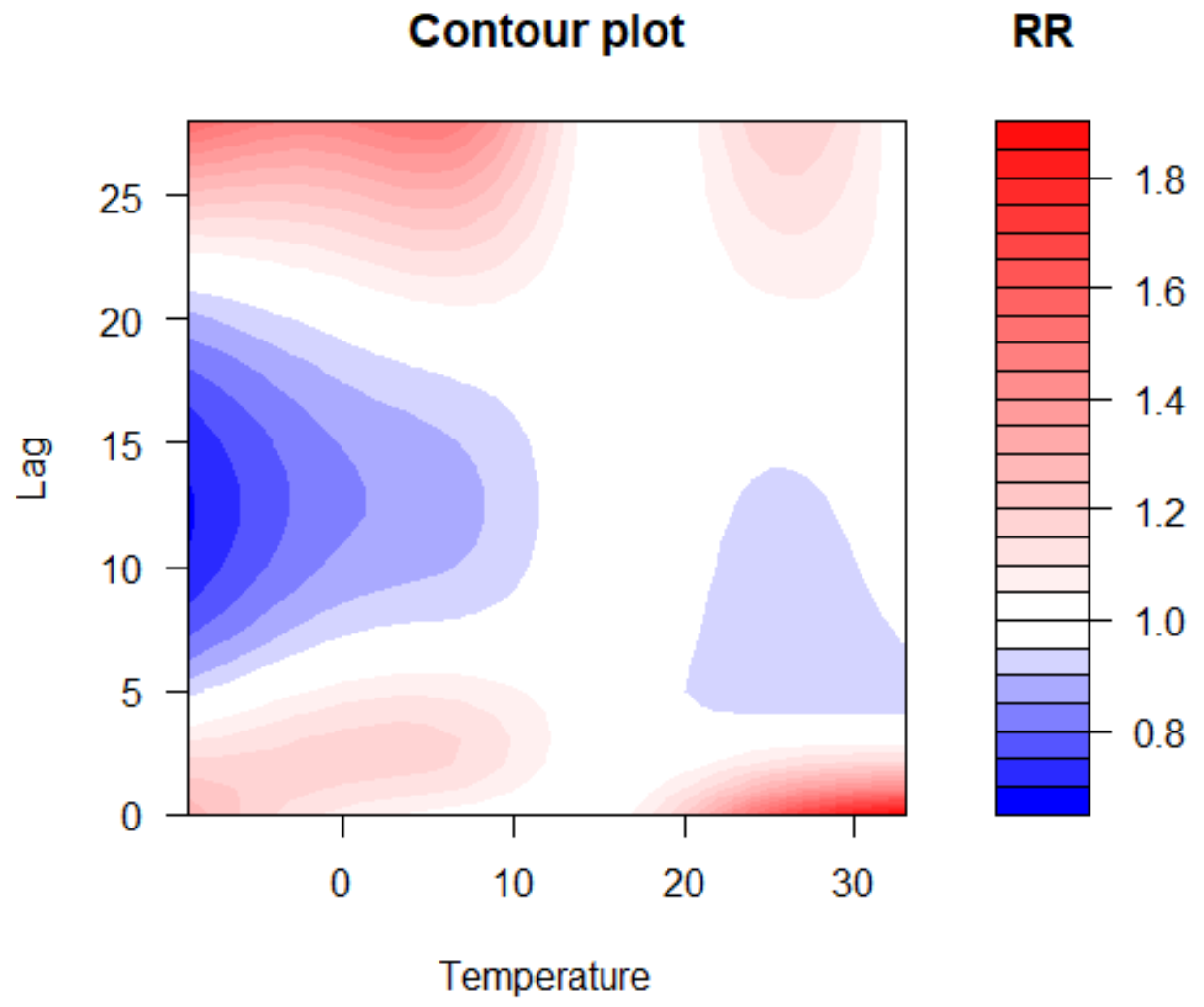

Figure 8D 
medRxiv preprint doi: https://doi.org/10.1101/2020.01.15.20017558; this version posted January 18, 2020. The copyright holder for this preprint (which was not certified by peer review) is the author/funder, who has granted medRxiv a license to display the preprint in perpetuity.

All rights reserved. No reuse allowed without permission.

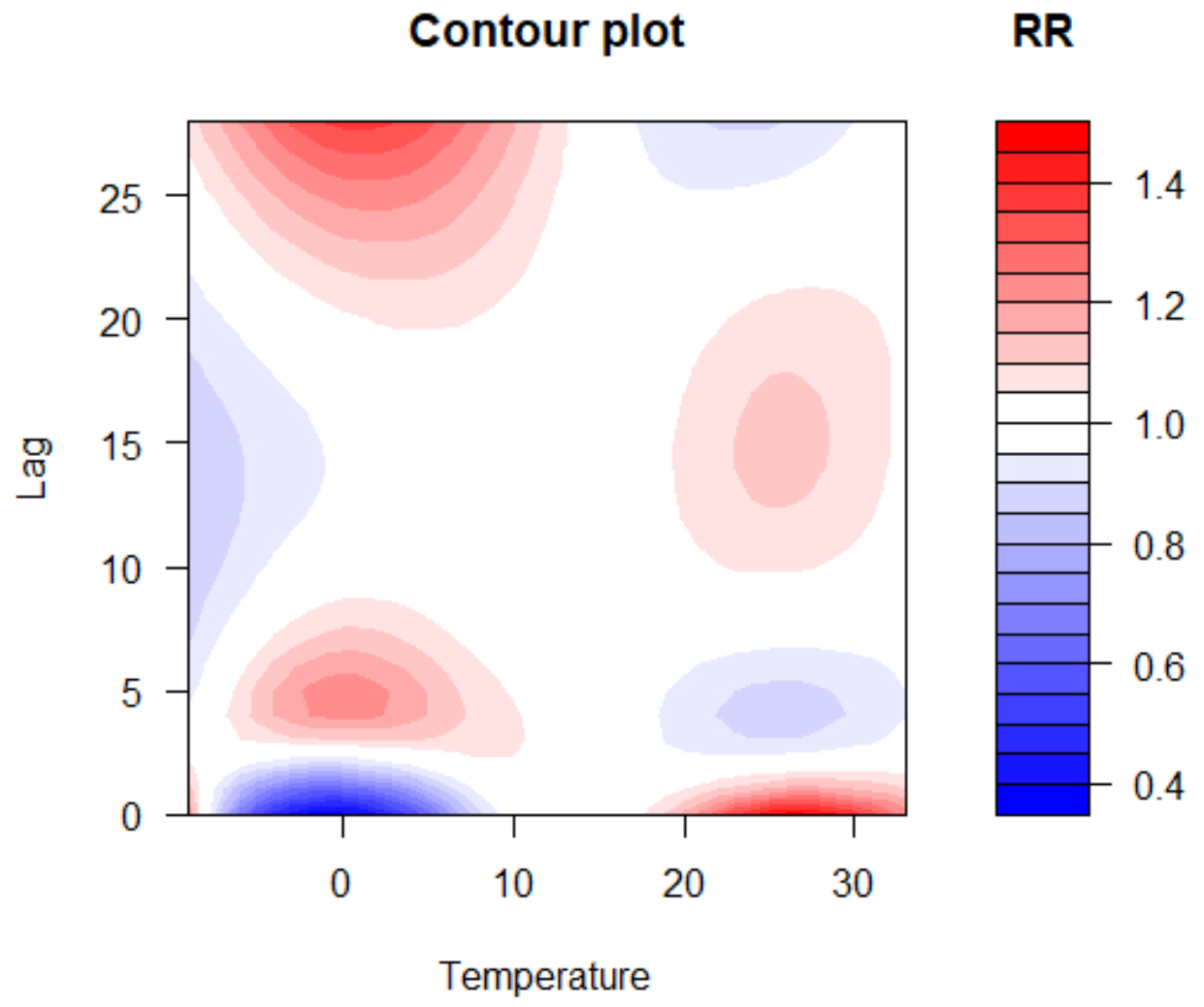

Figure 8E 
medRxiv preprint doi: https://doi.org/10.1101/2020.01.15.20017558; this version posted January 18, 2020. The copyright holder for this preprint (which was not certified by peer review) is the author/funder, who has granted medRxiv a license to display the preprint in perpetuity.

All rights reserved. No reuse allowed without permission.

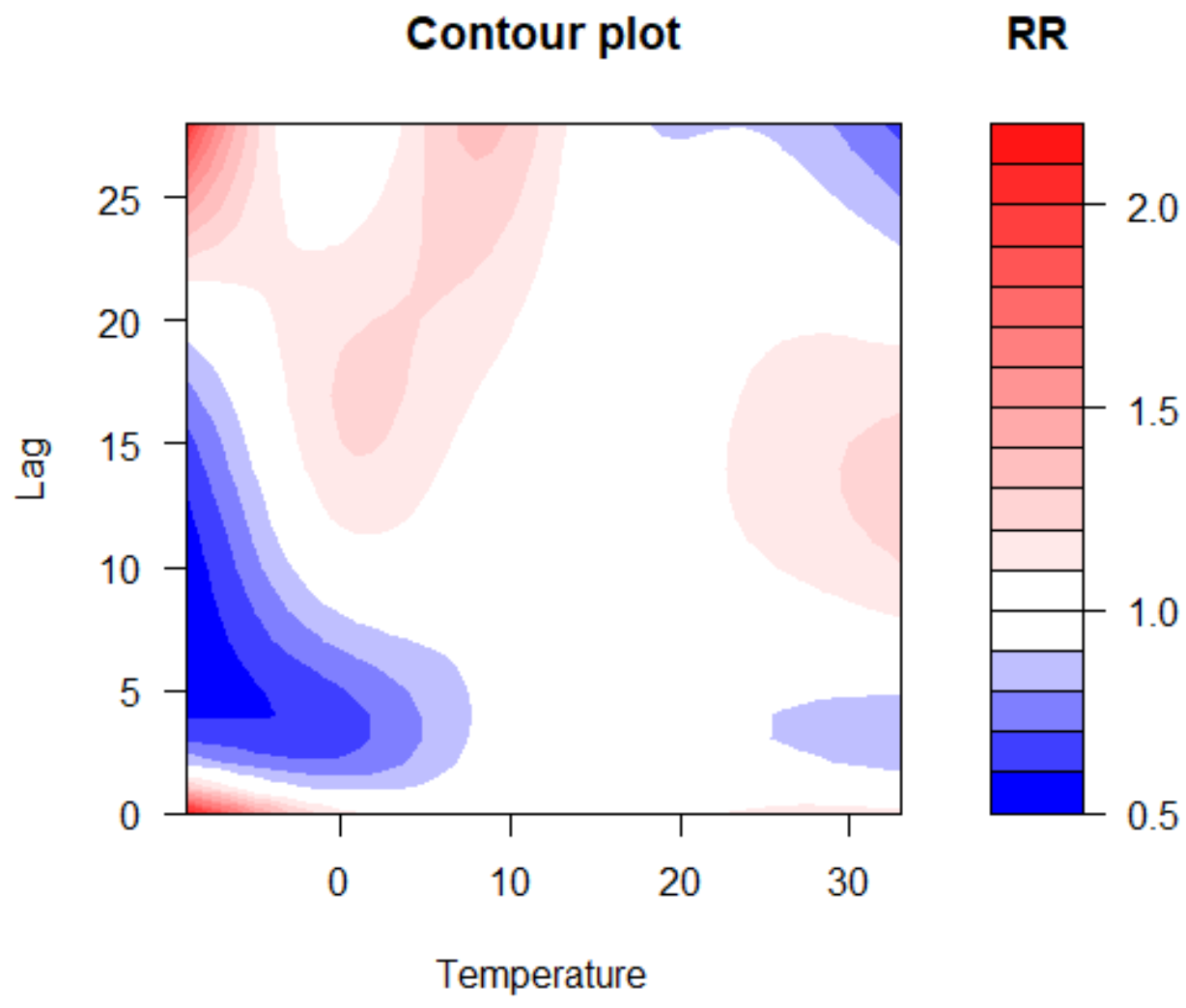

Figure 8F

Figure 8 Contour plots of lag-response to temperature based on the age stratification (A: age $\leq 30$ group; B: $30<$ age $\leq 40$ group; C:40<age $\leq 50$; D:50<age $\leq 60$; E: $60<$ age $\leq 70 ; \mathrm{F}$ : age $>70$ group) 
medRxiv preprint doi: https://doi.org/10.1101/2020.01.15.20017558; this version posted January 18, 2020. The copyright holder for this preprint (which was not certified by peer review) is the author/funder, who has granted medRxiv a license to display the preprint in perpetuity.

All rights reserved. No reuse allowed without permission.

\section{Lag Day=28}

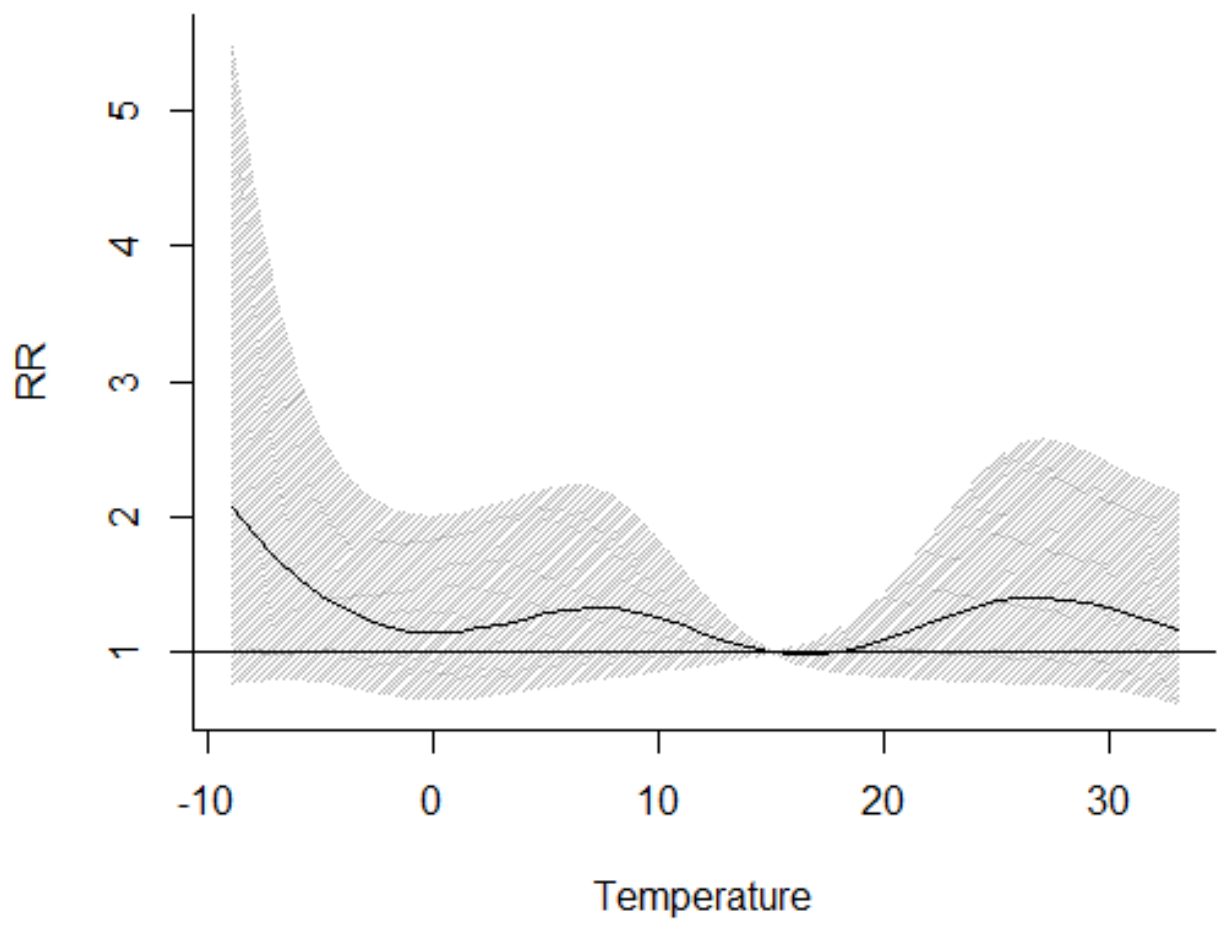

Figure 9A 
medRxiv preprint doi: https://doi.org/10.1101/2020.01.15.20017558; this version posted January 18, 2020. The copyright holder for this preprint (which was not certified by peer review) is the author/funder, who has granted medRxiv a license to display the preprint in perpetuity.

All rights reserved. No reuse allowed without permission.

\section{Lag Day=28}

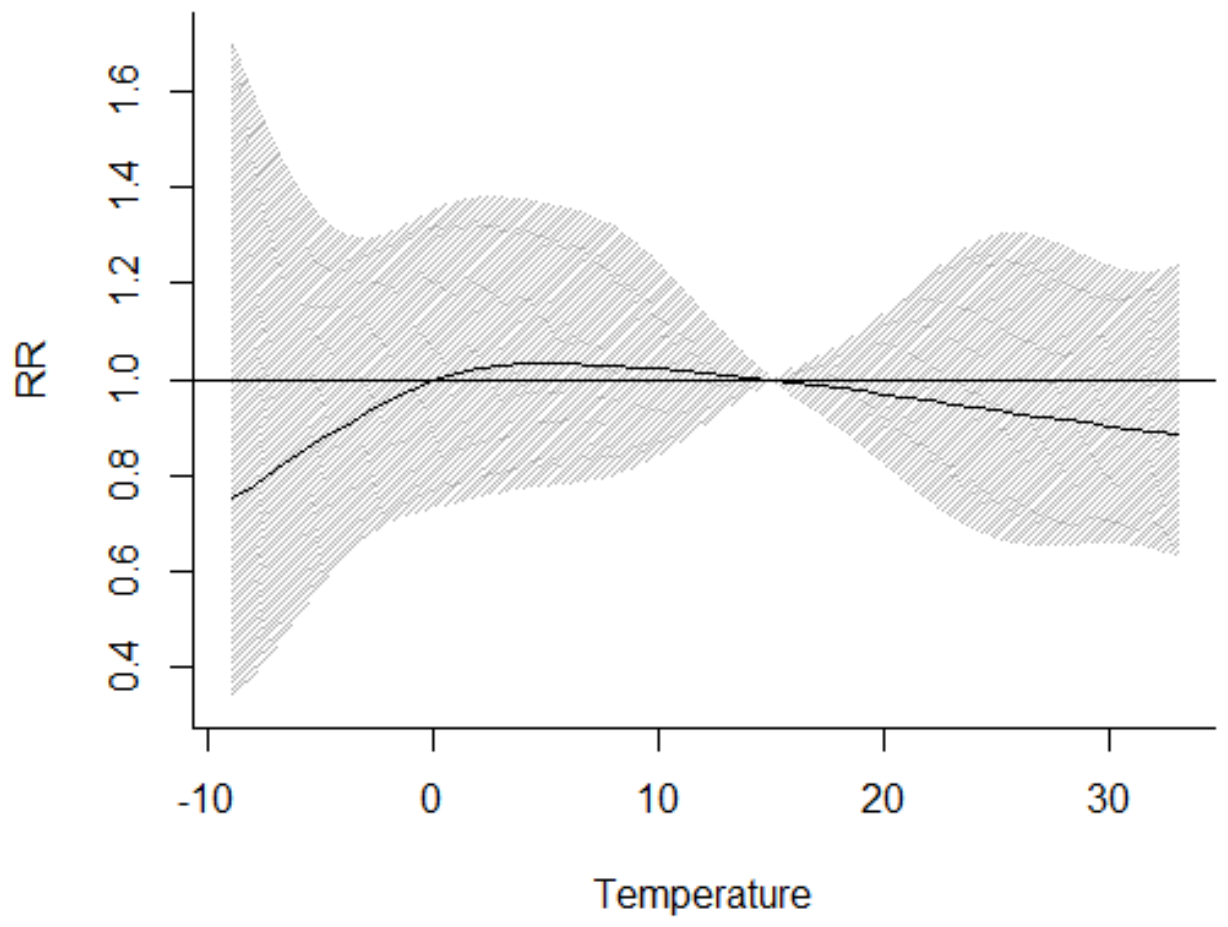

Figure 9B 
medRxiv preprint doi: https://doi.org/10.1101/2020.01.15.20017558; this version posted January 18, 2020. The copyright holder for this preprint (which was not certified by peer review) is the author/funder, who has granted medRxiv a license to display the preprint in perpetuity.

All rights reserved. No reuse allowed without permission.

\section{Lag Day=28}

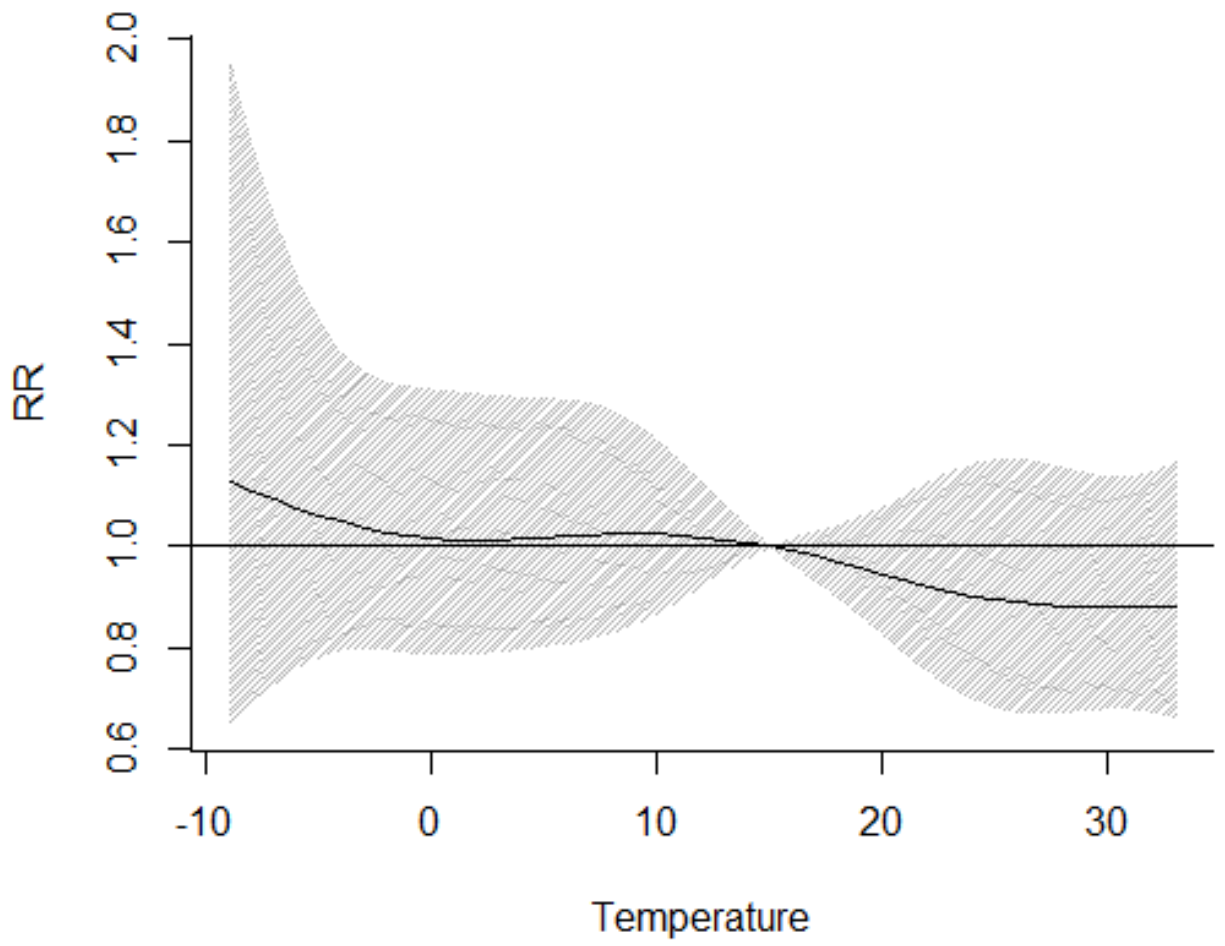

Figure 9C 
medRxiv preprint doi: https://doi.org/10.1101/2020.01.15.20017558; this version posted January 18, 2020. The copyright holder for this preprint (which was not certified by peer review) is the author/funder, who has granted medRxiv a license to display the preprint in perpetuity.

All rights reserved. No reuse allowed without permission.

\section{Lag Day=28}

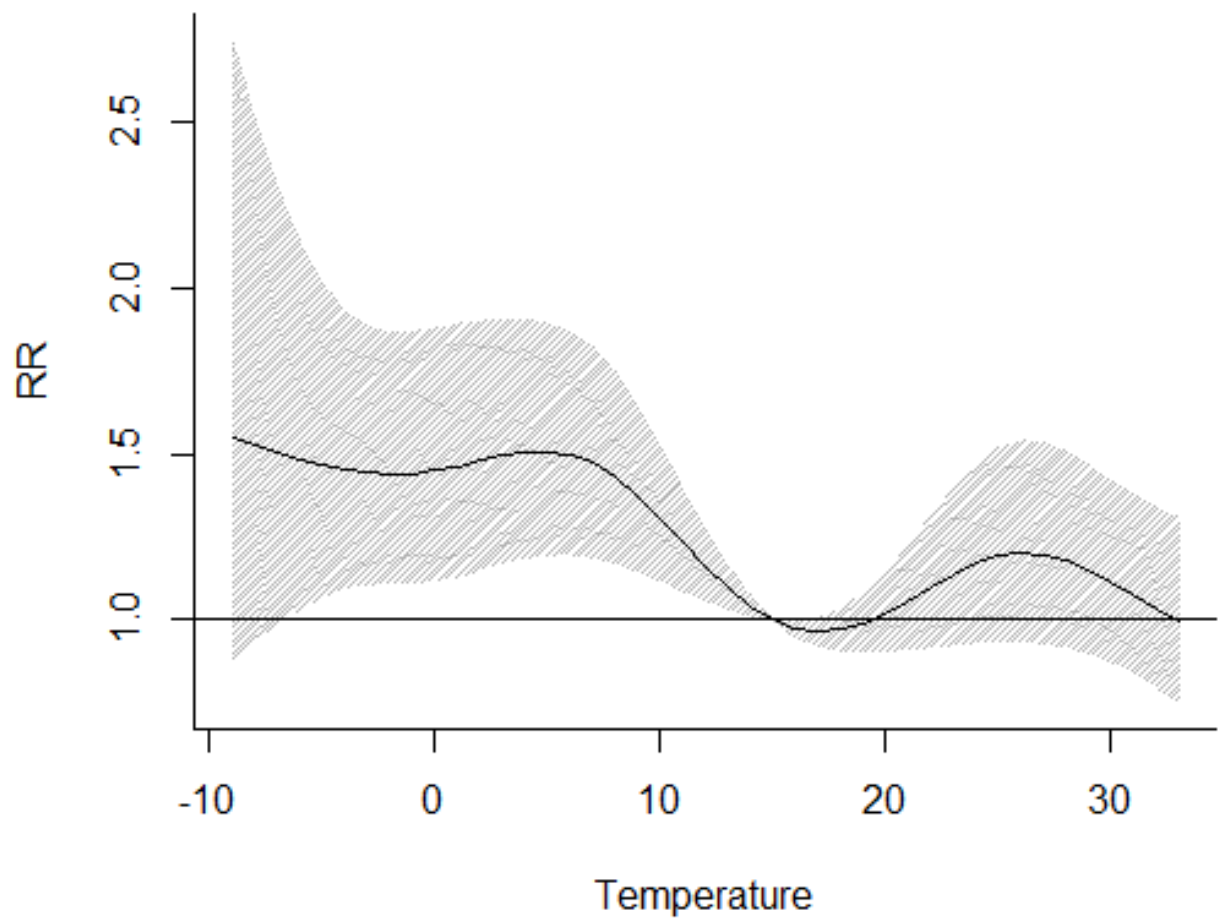

Figure 9D 
medRxiv preprint doi: https://doi.org/10.1101/2020.01.15.20017558; this version posted January 18, 2020. The copyright holder for this preprint (which was not certified by peer review) is the author/funder, who has granted medRxiv a license to display the preprint in perpetuity.

All rights reserved. No reuse allowed without permission.

\section{Lag Day=28}

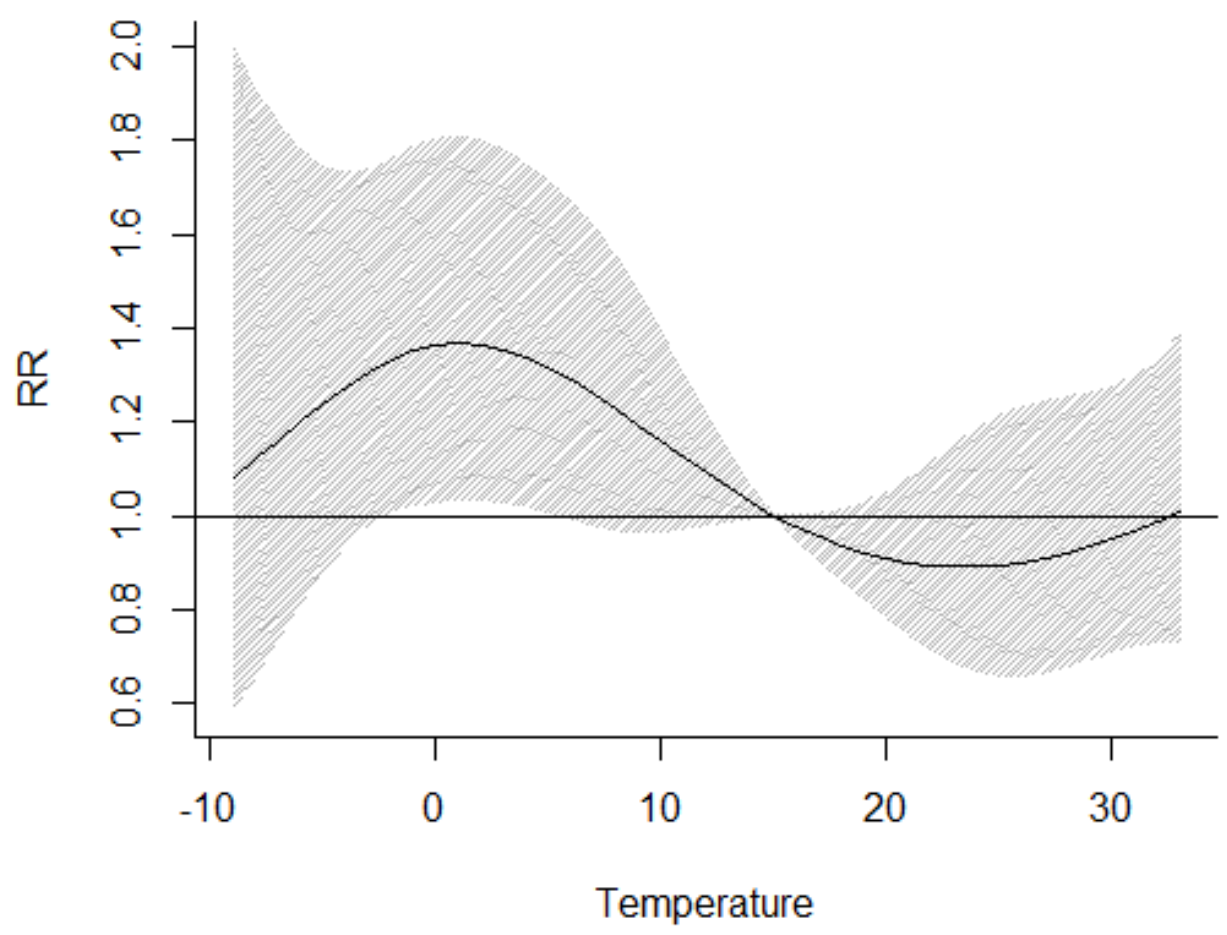

Figure 9E 


\section{Lag Day=28}

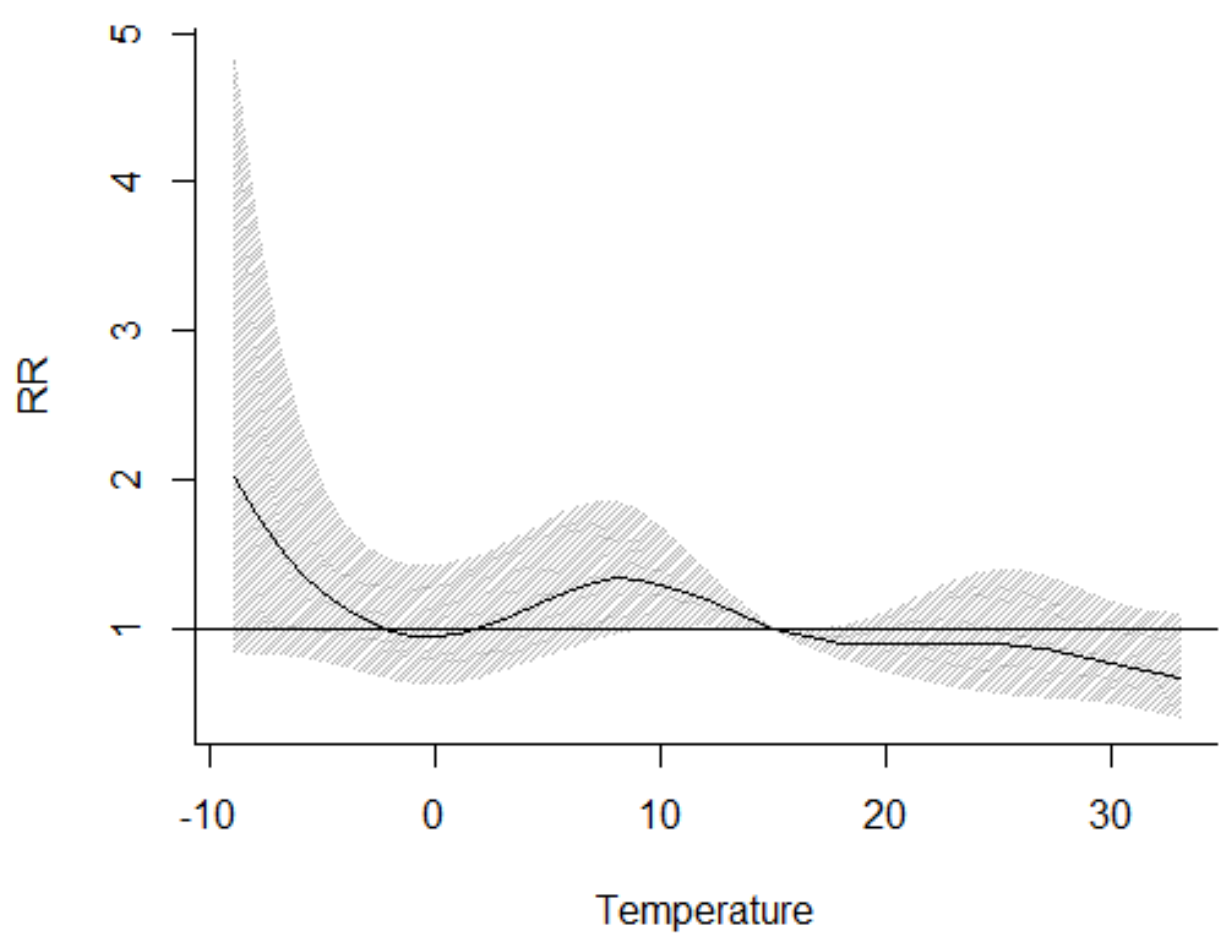

Figure 9F

Figure 9 The effect of temperature on the hospitalization when lag day was on 28 (A: age $\leq 30$ group; B: $30<a$ age $\leq 40$ group; C:40<age $\leq 50 ;$ D:50<age $\leq 60 ; \mathrm{E}: 60<$ age $\leq 70 ; \mathrm{F}:$ age $>70$ group) 